Review

\title{
Condensed Tannins as Antioxidants in Ruminants-Effectiveness and Action Mechanisms to Improve Animal Antioxidant Status and Oxidative Stability of Products
}

\author{
David Soldado $^{1,2}$, Rui J. B. Bessa ${ }^{2,3}$ (D) and Eliana Jerónimo ${ }^{1,4, *(\mathbb{D})}$ \\ 1 Centro de Biotecnologia Agrícola e Agro-Alimentar do Alentejo (CEBAL), Instituto Politécnico de \\ Beja (IPBeja), 7801-908 Beja, Portugal; david.soldado@cebal.pt \\ 2 Centro de Investigação Interdisciplinar em Sanidade Animal (CIISA), Avenida da Universidade Técnica, \\ 1300-477 Lisboa, Portugal; rjbbessa@fmv.ulisboa.pt \\ 3 Faculdade de Medicina Veterinária, Universidade de Lisboa, Avenida da Universidade Técnica, \\ 1300-477 Lisboa, Portugal \\ 4 MED-Mediterranean Institute for Agriculture, Environment and Development, Centro de Biotecnologia \\ Agrícola e Agro-Alimentar do Alentejo (CEBAL), 7801-908 Beja, Portugal \\ * Correspondence: eliana.jeronimo@cebal.pt
}

check for

updates

Citation: Soldado, D.; Bessa, R.J.B.; Jerónimo, E. Condensed Tannins as Antioxidants in

Ruminants-Effectiveness and Action Mechanisms to Improve Animal Antioxidant Status and Oxidative Stability of Products. Animals 2021, 11, 3243. https://doi.org/10.3390/ ani11113243

Academic Editor: Gonzalo Hervás

Received: 23 September 2021

Accepted: 12 November 2021

Published: 13 November 2021

Publisher's Note: MDPI stays neutral with regard to jurisdictional claims in published maps and institutional affiliations.

Copyright: (c) 2021 by the authors. Licensee MDPI, Basel, Switzerland. This article is an open access article distributed under the terms and conditions of the Creative Commons Attribution (CC BY) license (https:// creativecommons.org/licenses/by/ $4.0 /)$.
Simple Summary: Condensed tannins (CTs) are secondary plant metabolites known for their antinutritional properties but also for their beneficial attributes for animal health and food quality, including antioxidant activity. Condensed tannins sources, such as plants and agro-industrial by-products or extracts prepared from these vegetal materials, have been used in ruminant diets to improve the animal antioxidant status and the oxidative stability of their products. However, this nutritional strategy has shown inconsistent results. Furthermore, unlike other phenolic compounds with low molecular weight, CTs are high molecular weight oligomers and polymers with poor bioavailability, which limit their absorption into circulation and direct antioxidant effect in living animals and post-mortem. Therefore, the action mechanism by which dietary CT exerts an antioxidant effect on ruminants is poorly understood. So, this review briefly presents the chemical structure of tannins, with particular emphasis on CT chemical structure, summarizes several studies focused on the effect of dietary CT sources on ruminants' antioxidant status and oxidative stability of their products, and discusses the possible action mechanisms by which CT can exert such effects.

Abstract: Condensed tannins (CTs) are widely distributed in plants, and due to their recognized antioxidant activity are considered as possible natural antioxidants for application in ruminant diets. A wide range of CT-rich sources has been tested in ruminant diets, and their effects on animal antioxidant status and oxidative stability of their products are reviewed in the present work. Possible mechanisms underlying the CT antioxidant effects in ruminants are also discussed, and the CT chemical structure is briefly presented. Utilization of CT-rich sources in ruminant feeding can improve the animals' antioxidant status and oxidative stability of their products. However, the results are still inconsistent. Although poorly understood, the evidence suggests that CTs can induce an antioxidant effect in living animals and in their products through direct and indirect mechanisms, which can occur by an integrated and synergic way involving: (i) absorption of CTs with low molecular weight or metabolites, despite CTs' poor bioavailability; (ii) antioxidant action on the gastrointestinal tract; and (iii) interaction with other antioxidant agents. Condensed tannins are alternative dietary antioxidants for ruminants, but further studies should be carried out to elucidate the mechanism underlying the antioxidant activity of each CT source to design effective antioxidant strategies based on the use of CTs in ruminant diets.

Keywords: condensed tannins; ruminants; oxidative stress; antioxidant effect; mechanism of action; metabolism 


\section{Introduction}

Livestock species are frequently exposed to oxidative stress, generated by overproduction of free radicals that cannot be handled by the body's antioxidant defense capacity, resulting in oxidative damage of several vital cell components and deterioration of many physiological functions, such as growth, reproduction, and immunity [1,2].

Oxidative damage in cells and tissues results from the action of several reactive molecular species, generally designated as reactive oxygen (ROS) and nitrogen species (RNS), although some non-radical reactive derivatives of oxygen and nitrogen are also included [2] that are able to induce serious injuries in molecules, such as deoxyribonucleic acid (DNA), lipids, proteins and carbohydrates [3]. A normal cellular metabolism generates and eliminates ROS, both processes being closely related, resulting in a very low level of ROS in living organisms [3]. However, this balance can be disturbed under several circumstances [3] and an imbalance between oxidants and antioxidants in favor of the oxidants results in a status known as oxidative stress [4,5].

Several factors can create favorable conditions for the development of oxidative stress in farm animals. Lipid supplementation of ruminants' diets has been used for a long time to increase their energy density, and more recently to improve the fatty acid profile of ruminant products by inclusion of lipid sources rich in polyunsaturated fatty acids (PUFA) in diets [6-8]. However, due to PUFAs' high susceptibility to oxidation, these nutritional strategies expose the animals to oxidative stress conditions, while enhancing the susceptibility of products to oxidation which limits its quality and acceptability [5]. Nutritional imbalance, feed contamination, and the presence of mycotoxins are other oxidative stress factors [2]. High environmental temperatures are also associated with increased oxidative stress [9], which constitutes a major concern as to the possible impact of expected climate change with alarming temperature increases and more frequent and intense heat waves. In addition to diet and environmental aspects, other factors such as housing condition, animal management, transportation, mechanical injuries, disease and the physiological state of animals can contribute to oxidative imbalance $[2,10,11]$. These oxidative stress conditions lead to increased production of free radicals above the capacity of the antioxidant system to eliminate them. The excessive free radicals are available to cause oxidative damage to various cell macromolecules, a process by which more free radicals are generated, triggering a chain of oxidative destruction [12].

The animals' antioxidant status is also reflected in the quality of their products, determining a higher susceptibility or resistance to oxidative deterioration. Animal-derived foods are subjected to oxidative reactions, resulting in deterioration of color and development of undesirable odor and flavor, loss of nutrients such as essential fatty acids, vitamins, and other bioactive compounds, and production of compounds harmful to human health, a major cause of the quality loss in food $[13,14]$. These oxidative reactions are influenced by intrinsic and extrinsic factors that can promote or inhibit them. Processing and storage conditions are the external factors that mostly affect the oxidative stability of foods $[14,15]$. The lipid content and composition are one of the intrinsic parameters which great influence food's oxidative stability, with foods containing high amounts of unsaturated fatty acids, such as foods naturally rich or enriched in $n-3$ PUFA, highly susceptible to lipid oxidation $[16,17]$. Foods with high levels of prooxidants (e.g., hemeproteins, metals such as $\mathrm{Fe}$ and $\mathrm{Cu}$ ) are also particularly prone to oxidation [14]. In contrast, the presence of antioxidants can limit oxidative reactions and improve the shelf-life of foods [15].

When oxidative stress occurs, an adaptive stress response is triggered to minimize the damaging effects of free radicals, increasing the capability of antioxidant systems to eliminate the free radicals [3]. The endogenous antioxidant system—composed by antioxidant enzymes such as catalase (CAT), glutathione peroxidase (GPx) and superoxide dismutase (SOD), and by non-enzymatic antioxidants such as glutathione (GSH), alpha-lipoic acid, Coenzyme $Q$, ferritin, uric acid and bilirubin — plays crucial roles in maintaining the redox balance in the body [18]. Antioxidant compounds such as vitamins E, $C$ and $\beta$-carotene, which are naturally present in greater or lesser amounts in animal feed, are also strongly 
involved in the mechanisms of protection against free radicals in the living organism and products [5]. However, under certain circumstances, the endogenous antioxidant system and antioxidant compounds naturally present in the feedstock may not be enough to prevent oxidative damage, being fundamental to increase the levels of antioxidant compounds in the diet to ensure animal welfare and productivity, as well as the quality of products [2]. Synthetically manufactured antioxidants are largely used in animal nutrition [19], but to address consumer concerns on safety of these products there has been an increasing interest in the use of natural antioxidants in the diets of various farm animals.

As plant secondary metabolites, condensed tannins (CTs) are part of the plant chemical defense system against biotic and abiotic stressors [20,21]. Moreover, CTs present several biological activities with benefits for human and animal health and food quality. Antioxidant, anticancer, antidiabetic, anti-inflammatory, anthelmintic, antimicrobial, immunostimulant and cardio- and neuro- and eye-protective are some of the beneficial health properties of CTs [21-25]. Although they are also known for their antinutritional properties, several CT sources has been applied in livestock species diets with neutral and beneficial effects, such as prevention of bloating, control of internal parasites, reduction of methane production, improvement of the digestive utilization of feed proteins, the fatty acid composition of products, or the productive performance in ruminant animals [26-28]. Improved gastrointestinal health and growth performance are some of the beneficial effects of dietary CTs reported in monogastric animals [20,29].

Probably due to the association of various diseases with oxidative stress, the antioxidant activity has been one of the most studied biological effects of CTs, in both in vitro and in vivo models. The strong antioxidant capacity of CTs is demonstrated in several in vitro assays [30-32], and CT extracts have been successfully applied to retard lipid oxidation in foods [33,34]. Moreover, the antioxidant efficacy of CTs has also been verified in human and animal studies, including both ruminants and monogastric farm animals [21,23,24,26,33]. Due to their recognized antioxidant activity and wide distribution among the plant kingdom, CTs are appointed as good natural antioxidant candidates for application in ruminant diets. However, if the antioxidant effect of CTs is fully proven in in vitro studies and when they are directly added to food products, their in vivo and post-mortem antioxidant effects when applied in ruminant diets have been contradictory, with doubts remaining as to the effectiveness of this approach, as well as the action mechanisms. So, the main objective of the current review is to critically analyze the available knowledge on the effect of CT sources' incorporation in ruminant diets on animal antioxidant status and oxidative stability of their products and discuss the CT antioxidant mechanisms in ruminants. Tannins chemical structure will also be briefly reviewed.

\section{Condensed Tannins' Chemical Structure}

Tannins are a heterogeneous group of phenolic compounds that can be classified into 3 major groups based on their chemical structures: hydrolysable tannins (HTs), condensed tannins (CTs) and phlorotannins (PTs) [20,35]. The HTs and CTs are found in terrestrial plants, while PTs only appears in brown seaweeds [20,35]. Hydrolysable tannins contain a central unit of glucose or other polyols esterified with gallic acid, named gallotannins, or with heaxahydroxydiphenic acid, named ellagitannins [25]. Phlorotannins comprise a distinct set of polymers, structurally like terrestrial tannins, being formed by polymeric chains of phloroglucinol, connected via C-C and/or C-O-C bonds [36].

For the purposes of this review, our focus will be on the CTs. Known also as proanthocyanidins, CTs are oligomers and polymers composed of flavan-3-ols linked through C4-C8 and / or C4-C6 bonds, both called B-type CTs, and doubly linked with an additional ether bond at $\mathrm{C} 2 \rightarrow \mathrm{O} \rightarrow \mathrm{C} 7$ or $\mathrm{C} 2 \rightarrow \mathrm{O} \rightarrow \mathrm{C} 5$, designed as an A-type $\mathrm{CT}[23,37]$. The size of the $\mathrm{CT}$ molecule is characterized by its degree of polymerization, which varies between two and greater than fifty flavan-3-ols subunits [38]. The majority of CTs present in common forage species are mainly composed by four monomeric flavan-3-ol subunits, catechin and epicatechin, gallocatechin and epigallocatechin [39] (Figure 1A), which differ in the number 
and stereochemistry of hydroxyl groups and the relative stereochemistry of the substituents on the C-ring (i.e., cis or trans-configuration) $[39,40]$. The catechin and epicatechin differ from each other only in their stereochemistry of the hydroxyl $(\mathrm{OH})$ group at the $\mathrm{C} 3$ carbon on the $\mathrm{C}$-ring. The gallocatechin and epigallocatechin also differ from each other by the spatial orientation of the $\mathrm{OH}$ group at $\mathrm{C} 3$ on the $\mathrm{C}$-ring [39]. The stereochemistry of the $\mathrm{C} 2$ and C3 substituents in the C-ring also differ between flavan-3-ol subunits, in which epicatechin and epigallocatechin show cis orientation, whereas catechin and gallocatechin show trans orientation [39]. Moreover, catechin and epicatechin have two OH groups on the B-ring, and gallocatechin and epigallocatechin three $\mathrm{OH}$ groups on the B-ring [40]. In addition, few plants have CTs containing flavan-3-ol subunits that are modified with galloyl groups at the C3 hydroxyl position (Figure 1B), giving rise to catechin gallate, epicatechin gallate, gallocatechin gallate and epigallocatechin gallate [39]. According to flavan-3-ol subunit composition, CTs can be classified into different subgroups. The two major CT subgroups are procyanidin tannins (PC), composed by catechin and epicatechin and prodelphinidin tannins (PD), which have gallocatechin and epigallocatechin (Figure 1A) [37,39]. The CTs in common forage plants typically contain a complex mixture of PC and PD, while few plants only synthesize PC or PD [41].

A Subunits of Procyanidins (PC)<smiles>Oc1cc(O)c2c(c1)O[C@H](c1ccc(O)c(O)c1)[C@H](O)C2</smiles>

catechin<smiles>Oc1cc(O)c2c(c1)O[C@H](c1ccc(O)c(O)c1)[C@H](O)C2</smiles>

epicatechin

Subunits of Prodelphinidins (PD)<smiles>Oc1cc(O)c2c(c1)O[C@H](c1cc(O)c(O)c(O)c1)[C@H](O)C2</smiles><smiles>Oc1cc(O)c2c(c1)O[C@H](c1cc(O)c(O)c(O)c1)[C@H](O)C2</smiles>

B<smiles>CC(=O)c1cc(O)c(O)c(O)c1</smiles>

Figure 1. (A) Monomeric proanthocyanidins, subunits of procyanidins—catechin and epicatechin and subunits of prodelphinidin—gallocatechin and epigallocatechin; (B) galloyl group.

Taking into account the different pattern of hydroxylation, types of interflavan-3-ol linkages, stereochemistry of the $\mathrm{C} 2$ and $\mathrm{C} 3$ and degree of polymerization, a great structural diversity of CTs is found in plants [37]. Their structure has relevant influence on the chemistry and biological features of CTs, affecting their absorption and metabolism as well as the protein binding affinity, and the anthelmintic and antioxidant activities, [23,40]. For example, the protein precipitation increases with the CT size [39], and it is reported that the antioxidant activity of CTs is positively related to increase of the polymerization degree [31,42-44]. 


\section{Condensed Tannins as Antioxidants in Ruminant Diets}

A wide range of $\mathrm{CT}$ sources has been extensively tested in ruminant diets, as modulators of the ruminal biohydrogenation in order to improve the fatty acid profile of meat and milk fat [26,45], and as natural agents to reduce methane emissions, protect the protein against ruminal degradation, prevent bloating, control internal parasites, and improve animals' antioxidant status and oxidative stability of their products $[20,27,28,39,46-48]$. The CT sources applied in these nutritional strategies for ruminants include plants (legumes, trees and shrubs) and by-products containing high CT contents or extracts with variable $\mathrm{CT}$ purity obtained from these plants and by-products. Despite the large number of CT sources applied in ruminant diets, only a few of them have been tested in terms of their efficacy to improve the animal antioxidant status and limit the oxidative deterioration of products. Standing out are by-products from of wine industry, which are used in their original form (grape pomace) or in the form of extracts (e.g., grape seed extract), by-products from other fruits (carob pulp and peanut skin) and from the forest (pine bark), foliage and extracts from endemic shrubs and trees (e.g., Cistus ladanifer, quebracho and mimosa), and widespread legumes forages (sainfoin and sorghum). Plants or by-products rich in CTs may represent a greater proportion of the diet (50-750 g/ $\mathrm{kg}$ dry matter (DM), Table 1) and provide other nutrients and bioactive compounds in addition to CTs, while CT extracts, which contain high levels of CTs (more than $40 \%$ and reaching 95\%), are usually incorporated into diets at lower levels (Table 2). So, the antioxidant impact of CT sources applied in ruminant diets will be presented and discussed according to the applied strategy, separating the strategies based in use of CT-rich plants or by-products from CT extracts.

\subsection{Condensed Tannin-Rich Plants and Agro-Industrial By-Products}

Grape pomace, consisting of grape seeds, skin and pulp, is one of the most studied CT sources in terms of its efficacy to improve ruminants' antioxidant status and the oxidative stability of their products. Inclusion of 50 and $100 \mathrm{~g} / \mathrm{kg}$ DM of red wine grape pomace in lamb diets resulted in the improvement of several muscle antioxidant status parameters [49]. A reduction of lipid oxidation, indicated by lower levels of malondialdehyde (MDA), one of the most abundant aldehydes derived from the oxidation of PUFA, and increased total antioxidant capacity and activity of antioxidant enzyme GPx4 in muscle were observed when $100 \mathrm{~g} / \mathrm{kg}$ DM of grape pomace was incorporated in lamb diets [49]. A lower grape pomace level—50 g/kg DM-was enough to reduce the reactive oxygen species (ROS) content and to increase the SOD activity in muscle [49]. In the same experiment, authors also evaluated the effect of dietary grape pomace inclusion on antioxidant capacity in the testes of ram lambs maintained under housing situations that can lead to increased oxidative stress [50]. The results showed that grape pomace inclusion in diets reduced the ROS and MDA contents in testes of confined lambs to values similar to those found in lambs raised under free-range conditions [50]. Moreover, higher activity of CAT, SOD and GPx4 was also observed in testes of confined lambs that received grape pomace [50]. Inclusion of 50 and $100 \mathrm{~g} / \mathrm{kg}$ DM of grape pomace in lactating ewes' diet was also effective in preventing the lipid oxidation and metmyoglobin formation in suckling lamb meat packaged under high oxygen atmospheres $\left(80 \%\right.$ of $\mathrm{O}_{2}$ and $20 \%$ of $\left.\mathrm{CO}_{2}\right)$ after 10 days of storage in retail conditions [51]. Conversely, in lamb meat samples also packaged under high $\mathrm{O}_{2}: \mathrm{CO}_{2}$ atmosphere and stored at $2{ }^{\circ} \mathrm{C}$ during 14 days, there was no improvement of the lipid and myoglobin stability when $50 \mathrm{~g} / \mathrm{kg}$ DM of pomace grape was included in the concentrate supplied to the lambs [52]. 
Table 1. Antioxidant effect of utilization of condensed tannin-rich plants and agro-industrial by-products in ruminant diets.

\begin{tabular}{|c|c|c|c|c|c|c|c|}
\hline \multirow[b]{2}{*}{ Animal } & \multicolumn{2}{|c|}{ Source } & \multirow{2}{*}{$\begin{array}{l}\text { CT Level in Diets } \\
\text { (g/kg DM) }\end{array}$} & \multirow[b]{2}{*}{ Basal Diet } & \multirow[b]{2}{*}{ Sample } & \multirow[b]{2}{*}{ Effect } & \multirow[b]{2}{*}{ References } \\
\hline & Plant & $\begin{array}{l}\text { Level in Diet } \\
\text { (g/kg DM) }\end{array}$ & & & & & \\
\hline Lamb & Grape pomace & 50 and $100^{1}$ & - & $\begin{array}{l}\text { Corn, soybean meal, wheat bran, } \\
\text { oil cake of flax seed, naked oat } \\
\text { straw and potato rattan }\end{array}$ & muscle and testes & $\begin{array}{c}\downarrow R O S \text { and MDA levels; } \uparrow \text { Total } \\
\text { antioxidant capacity; } \uparrow \text { activity of } \\
\text { GPx } 4 \text { and SOD in muscle and } \\
\text { testes; } \uparrow \text { activity of CAT in testes }\end{array}$ & {$[49,50]$} \\
\hline Lamb & Grape pomace & 51.7 and 103 & 2.21 and 4.41 & $\begin{array}{c}\text { Forage:concentrate }(40: 60) \\
\text { supplemented with } 2.7 \% \text { of } \\
\text { linseed oil supplied to dams }\end{array}$ & muscle & $\begin{array}{l}\downarrow \text { MDA levels and } \mathrm{MMb} \% \text { in } \\
\text { suckling lambs }\end{array}$ & [51] \\
\hline Lamb & Grape pomace & 50 & $2.23^{4}$ & $\begin{array}{l}\text { Barley straw and concentrate ad } \\
\text { libitum; grape pomace included in } \\
\text { concentrate }\end{array}$ & muscle & $=\mathrm{MDA}$ levels and $\mathrm{MMb} \%$ & {$[52]$} \\
\hline Lamb & Grape pomace & $50,100,150$ and $200^{2}$ & $\begin{array}{l}2.7 ; 3.5 ; 4.9 \text { and } 6.0^{5} \\
0.8 ; 1.2 ; 1.8 \text { and } 2.6^{6}\end{array}$ & Concentrate: lucerne meal (80:20) & muscle & $\begin{array}{l}\uparrow \text { FRAP values from day } 1 \text { to day } 3 \\
\text { in the diets with } 150 \text { and } 200 \mathrm{~g} / \mathrm{kg} \\
\text { grape pomace; } \downarrow \text { MDA levels from } \\
\text { day } 5 \text { onward in the diets with } 200 \\
\mathrm{~g} / \mathrm{kg} \text { grape pomace; } \downarrow \text { carbonyl } \\
\text { content at days } 5 \text { and } 7 \text { of storage }\end{array}$ & [53] \\
\hline Steers & Grape pomace & $150^{2}$ & $\begin{array}{l}50.7^{5} \\
24.1^{7}\end{array}$ & $\begin{array}{l}\text { Wheat straw: concentrate: lucerne } \\
\qquad(9: 80: 10)\end{array}$ & muscle & $\begin{array}{c}\uparrow \text { FRAP values; } \downarrow \text { MDA and } \\
\text { carbonyl levels }\end{array}$ & {$[54]$} \\
\hline Cow & $\begin{array}{l}\text { Grape pomace } \\
\text { silage }\end{array}$ & 50,75 and 100 & - & $\begin{array}{l}\text { Silage: concentrate (60:40); grape } \\
\text { pomace silage replace partially the } \\
\text { corn silage in forage }\end{array}$ & milk & $\begin{array}{l}\uparrow \text { reducing power; = production of } \\
\text { conjugated diene hydroperoxides }\end{array}$ & {$[55]$} \\
\hline Lamb & Carob pulp & 240 and $350^{2}$ & 3.4 and $4.5^{8}$ & $\begin{array}{l}\text { Concentrate: dehydrated lucerne } \\
(80: 20) ; \text { carob pulp replaces } \\
\text { partially barley of the concentrate }\end{array}$ & muscle & $\begin{array}{l}=\text { MDA levels, free thiol and } \\
\text { carbonyl levels and } \mathrm{MMb} \%\end{array}$ & [56] \\
\hline Goat & Pine bark & - & $130^{4}$ & $\begin{array}{c}\text { Rye grass pasture supplemented } \\
\text { with mixture of pine bark with } \\
\text { molasses }(6 \% w / w) \text { and alfalfa }(5 \% \\
w / w) \text { containing } 130 \mathrm{~g} / \mathrm{kg} \mathrm{DM} \\
\text { of CT }\end{array}$ & muscle & $=$ MDA levels & [57] \\
\hline
\end{tabular}


Table 1. Cont.

\begin{tabular}{|c|c|c|c|c|c|c|c|}
\hline \multirow[b]{2}{*}{ Animal } & \multicolumn{2}{|c|}{ Source } & \multirow{2}{*}{$\begin{array}{l}\text { CT Level in Diets } \\
\text { (g/kg DM) }\end{array}$} & \multirow[b]{2}{*}{ Basal Diet } & \multirow[b]{2}{*}{ Sample } & \multirow[b]{2}{*}{ Effect } & \multirow[b]{2}{*}{ References } \\
\hline & Plant & $\begin{array}{l}\text { Level in Diet } \\
\text { (g/kg DM) }\end{array}$ & & & & & \\
\hline Goat & Peanut skin & $250 ; 500$ and $750^{2}$ & $39 ; 78$ and $117^{2}$ & $\begin{array}{l}\text { Concentrate (cracked corn, soybean } \\
\text { meal, soy hull and molasses) and } \\
\text { peanut skin }\end{array}$ & muscle & $\begin{array}{c}=\text { MDA levels in diets with } 500 \text { and } \\
750 \mathrm{~g} / \mathrm{kg} \text { peanut skin }\end{array}$ & {$[58]$} \\
\hline Lamb & Cistus ladanifer L. & 250 & $20.9^{9}$ & $\begin{array}{l}\text { Dehydrated lucerne supplemented } \\
\text { with } 0 \text { or } 6 \% \text { of a blend of sunflower } \\
\text { and linseed oils }(1: 2, v / v)\end{array}$ & muscle & $\begin{array}{c}\downarrow \text { MDA levels after lipid oxidation } \\
\text { induction }\end{array}$ & [59] \\
\hline Lamb & Cistus ladanifer L. & 50,100 and 200 & $2.7 ; 6.9$ and $15.6^{9}$ & $\begin{array}{l}\text { Concentrate: dehydrated lucerne } \\
\text { (50:50); supplemented with } 0,4 \text { and } \\
8 \% \text { of a blend of soybean and } \\
\text { linseed oils }(1: 2, v / v) ; \text { Cistus ladanifer } \\
\text { replaces partially the forage }\end{array}$ & muscle & $\begin{array}{c}\downarrow \text { MDA levels; } \downarrow \text { MDA levels after } \\
\text { lipid oxidation induction; } \uparrow \\
\alpha \text {-tocopherol content; =total } \\
\text { phenolic content, FRAP and TEAC } \\
\text { values }\end{array}$ & {$[60,61]$} \\
\hline Lamb & Cistus ladanifer L. & 150 & $3.5-5.6^{9}$ & $\begin{array}{c}\text { Concentrate: dehydrated lucerne } \\
\text { (50:50); supplemented with } 5-6 \% \text { of } \\
\text { soybean oil; Cistus ladanifer replaces } \\
\text { partially the forage }\end{array}$ & muscle & $=$ MDA levels & {$[62]$} \\
\hline \multirow{2}{*}{ Goat } & Larrean divaricata & $125^{2}$ & 1.74 & \multirow{2}{*}{ Alfalfa hay, corn and soybean meal } & \multirow{2}{*}{ muscle } & \multirow{2}{*}{$\begin{array}{l}=\mathrm{DPPH} \text { values; }=\text { total phenolic } \\
\text { content; } \downarrow \text { MDA levels in meat } \\
\text { stored at } 4{ }^{\circ} \mathrm{C} \text { over } 6 \text { days, at } 26^{\circ} \mathrm{C} \\
\text { for } 6 \mathrm{~h} \text { and at }-18{ }^{\circ} \mathrm{C} \text { for } 30 \text { days }\end{array}$} & \multirow{2}{*}[63]{} \\
\hline & Acacia aroma & $125^{2}$ & 5.63 & & & & \\
\hline Goat & Acacia farnesiana & 100,200 and 300 & - & Lucerne hay and concentrate & milk & $\begin{array}{c}\uparrow \text { total phenolic content; =catechin } \\
\text { concentration; } \uparrow \text { ORAC and FRAP } \\
\text { values }\end{array}$ & {$[64]$} \\
\hline Cow & Ficus infectoria & $119^{2}$ & $15^{4}$ & $\begin{array}{c}\text { Rice straw, maize green and } \\
\text { concentrate (maize, mustard cake } \\
\text { and rice bran); Ficus infectoria leaves } \\
\text { included in concentrate replacing } \\
\text { rice bran }\end{array}$ & erythrocytes & $\begin{array}{c}\uparrow \text { SOD and CAT activity; } \uparrow \text { GSH } \\
\text { levels; } \\
\downarrow \text { MDA levels; } \uparrow \text { total thiol levels }\end{array}$ & {$[65]$} \\
\hline Lamb & Ficus infectoria & 106,159 and $212^{2}$ & $10 ; 15$ and $20^{4}$ & $\begin{array}{l}\text { Wheat straw, green fodder, and } \\
\text { concentrate; Ficus infectoria leaves } \\
\text { replacing partially the wheat bran of } \\
\text { the concentrate }\end{array}$ & erythrocytes & $\begin{array}{c}\uparrow \text { SOD and CAT activity; } \uparrow \text { GSH } \\
\text { levels; } \downarrow \text { MDA levels; } \uparrow \text { total thiol } \\
\text { and protein thiol levels }\end{array}$ & [66] \\
\hline
\end{tabular}


Table 1. Cont.

\begin{tabular}{|c|c|c|c|c|c|c|c|}
\hline \multirow[b]{2}{*}{ Animal } & \multicolumn{2}{|c|}{ Source } & \multirow{2}{*}{$\begin{array}{l}\text { CT Level in Diets } \\
\text { (g/kg DM) }\end{array}$} & \multirow[b]{2}{*}{ Basal Diet } & \multirow[b]{2}{*}{ Sample } & \multirow[b]{2}{*}{ Effect } & \multirow[b]{2}{*}{ References } \\
\hline & Plant & $\begin{array}{l}\text { Level in Diet } \\
\text { (g/kg DM) }\end{array}$ & & & & & \\
\hline Lamb & $\begin{array}{l}\text { Ficus infectoria and } \\
\text { Psidium guajava } \\
(70: 30)\end{array}$ & $96 ; 144$ and $192^{3}$ & $10 ; 15$ and $20^{4}$ & $\begin{array}{l}\text { Wheat straw, oat hay and } \\
\text { concentrate (maize, wheat bran, } \\
\text { deoiled soybean meal); leaf meal } \\
\text { mixture replace the concentrate }\end{array}$ & erythrocytes & $\begin{array}{c}\uparrow \text { SOD, GPx and CAT activity; } \uparrow \\
\text { GSH and GST levels; } \uparrow \text { total thiol } \\
\text { and protein thiol levels; =MDA } \\
\text { levels }\end{array}$ & [67] \\
\hline Goat & $\begin{array}{l}\text { Oak (Quercus } \\
\text { leucotrichophora) }\end{array}$ & - & $33.5^{4}$ & $\begin{array}{c}\text { Concentrate: oak leaves as } \\
\text { roughage }\end{array}$ & erythrocytes & $\begin{array}{c}\uparrow \text { SOD and CAT activity; } \uparrow \text { GSH } \\
\text { levels }\end{array}$ & [68] \\
\hline Lamb & $\begin{array}{c}\text { Sainfoin } \\
\text { (Onobrychis viccifolia) }\end{array}$ & - & $5.59-6.71^{4,8}$ & $\begin{array}{l}\text { Silage mixture of timothy and } \\
\text { sainfoin }(50: 50) \text { ad libitum, straw } \\
(60-80 \mathrm{~g} / \mathrm{d}) \text { and barley }(229 \mathrm{~g} / \mathrm{d})\end{array}$ & muscle & $\begin{array}{c}=\text { MDA levels in raw meat; } \downarrow \text { MDA } \\
\text { levels under pro-oxidant } \\
\text { conditions (cooking and } \\
\text { incubation with pro-oxidant } \\
\text { catalysts) }\end{array}$ & [69] \\
\hline Lamb & $\begin{array}{c}\text { Sainfoin } \\
\text { (Onobrychis viccifolia) }\end{array}$ & - & $21.9^{10}$ & Sainfoin pasture supplied to dams & muscle & $\downarrow$ MDA levels suckling lambs & [70] \\
\hline Steers & $\begin{array}{l}\text { High-tannin } \\
\text { sorghum }\end{array}$ & $383-765$ & $17.3-34.6^{11}$ & $\begin{array}{l}\text { Silage:concentrate (10:90); } \\
\text { high-tannin sorghum replace } \\
\text { partially the corn of the } \\
\text { concentrate }\end{array}$ & muscle & $\begin{array}{c}\downarrow \downarrow \text { MDA levels in } \\
\text { vacuum-packaged beef; } \uparrow \text { MDA } \\
\text { levels in displayed beef over 6, } 10 \\
\text { and } 15 \text { days; =SOD, CAT and GPx } \\
\text { activity }\end{array}$ & {$[71]$} \\
\hline Lamb & Sorghum grain & $100 ; 200$ and 400 & $8.2 ; 16.4$ and $24.5^{11}$ & $\begin{array}{l}\text { Forage (Aneurolepidium Chinense } \\
\text { hay and alfalfa hay):concentrate } \\
\text { (corn grain and soybean meal) } \\
\text { (42:58). Stepwise replacement of } \\
\text { corn grain by sorghum grain }\end{array}$ & muscle & $=$ MDA levels; $\uparrow$ tannin levels & {$[72]$} \\
\hline
\end{tabular}

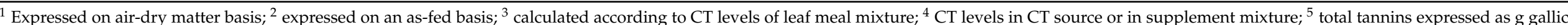

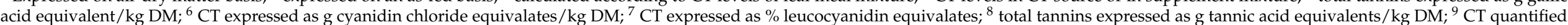

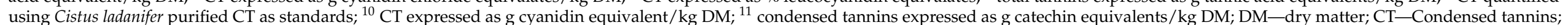

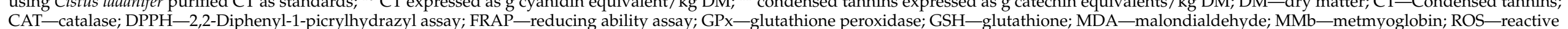
oxygen species; SOD—superoxide dismutase; TEAC—radical scavenging ability, $\uparrow$-increase; $\downarrow$-reduction. 
Higher levels of grape pomace in lamb diets than those tested by other authors (50, 100, 150 and $200 \mathrm{~g} / \mathrm{kg} \mathrm{DM}$ ) were used in experiments by Chikwanha et al. [53]. The muscle antioxidant activity, evaluated by ferric reducing ability (FRAP) assay decreased over 9 days of storage independently of the grape pomace level in the diet; however, during the first 3 days of storage higher values of antioxidant activity were observed in muscle from lambs fed diets containing 150 and $200 \mathrm{~g} / \mathrm{kg}$ DM of grape pomace than those fed diets with lower levels of grape pomace. From day 5 to day 9 , the difference between the diets was less expressive, but during all storage periods the diet containing of $200 \mathrm{~g} / \mathrm{kg}$ DM of grape pomace resulted in higher muscle antioxidant activity than a control diet without grape pomace [53]. Consistently, feeding $200 \mathrm{~g} / \mathrm{kg}$ DM of grape pomace also resulted in the lowest MDA and carbonyl contents in meat from the 5th day of storage [53]. Reduction of the MDA and carbonyl contents and increase of the antioxidant activity (FRAP assay) were also observed in beef when $150 \mathrm{~g} / \mathrm{kg}$ DM of grape pomace was included in steers diets [54].

In previous studies, the grape pomace was previously dried after incorporation into the diets. Ensiling the grape pomace is an alternative way to conserve this by-product. Inclusion of grape pomace silage ( 50,75 and $100 \mathrm{~g} / \mathrm{kg} \mathrm{DM})$ in the soybean oil-supplemented diet (40 g/ kg DM of soybean oil) of dairy cows increased the reducing power of milk to reduce the ferric ions [55]. However, the improvement of antioxidant capacity in milk did not result in reduction of the production of conjugated diene hydroperoxides, a primary product of lipid oxidation [55].

Carob pulp is an agro-industrial by-product widely available in the Mediterranean area and commonly used in animal feed [73], which is characterized by its high levels of CTs [74]. However, the effectiveness of carob pulp to improve the oxidative stability of lipids and proteins of lamb meat was not proven when two doses of carob pulp (240 and $350 \mathrm{~g} / \mathrm{kg}$ ) were included in diets [56].

Other agro-industrial by-products rich in CTs were also tested in ruminant diets, although the results on their antioxidant effect are still limited. Supplementation of goat diets with pine bark, a by-product of the timber industry containing up to $130 \mathrm{~g} / \mathrm{kg} \mathrm{DM}$ of CTs, also did not affect the meat MDA levels [57]. Meat lipid oxidation was also not affected by inclusion in goat diets of high levels of peanut skin (500 and $750 \mathrm{~g} / \mathrm{kg}$ ), a by-product of the peanut industry [58].

The utilization of endemic species due to their richness in CTs has been another approach to supply CTs in ruminant diets. The aerial part of Cistus ladanifer, a perennial shrub very abundant in the Mediterranean area rich in CTs (32-161 g/ kg DM of CTs [75]), has been applied in lamb diets with an approach to limit meat lipid oxidation. Incorporation of $250 \mathrm{~g} / \mathrm{kg}$ DM of Cistus ladanifer (leaves and soft stems) in a high-forage diet, supplemented or not with $6 \%$ of a blend of soybean and linseed oils $(1: 2, v / v)$, reduced the MDA levels in meat after lipid oxidation induction [59]. As expected, lipid oxidation increased throughout the 7 days of storage at $2{ }^{\circ} \mathrm{C}$, but lower MDA levels were observed in meats from lambs fed with Cistus ladanifer, showing the effectiveness of the dietary Cistus ladanifer to enhance the meat's resistance against lipid oxidation, even in PUFA-enriched meat [59]. Increased resistance against lipid oxidation of lamb meat was confirmed in another work, where increasing levels of Cistus ladanifer (50, 100 and $200 \mathrm{~g} / \mathrm{kg} \mathrm{DM}$ ) were incorporated in a forage and concentrate diet (1:1) supplemented with 0,40 and $80 \mathrm{~g} / \mathrm{kg}$ DM of soybean and linseed oils $(1: 2, v / v)$ [61]. These results were obtained using a methodology where the lipid oxidation products (MDA) were determined after the lipid oxidation induction [76], not allowing evaluation of the real lipid damage in meat. Nevertheless, the effectiveness of the dietary Cistus ladanifer to reduce the lipid oxidation in lamb meat without oxidative induction has also been proven $[60,61]$. These papers report that, independently of the dietary oil supplementation level, increasing levels of Cistus ladanifer (50, 100 and $200 \mathrm{~g} / \mathrm{kg} \mathrm{DM}$ ) in diets gradually reduced the MDA levels in meat samples stored for 7 days at $2{ }^{\circ} \mathrm{C}$ [61]. Despite that, the muscle antioxidant status evaluated by ferric reducing ability (FRAP 
assay) and radical scavenging ability (TEAC assay) and the total phenolic content of muscle was unaffected by increasing levels of Cistus ladanifer in the diet [61]. In this experiment, all diets were supplemented with the same levels of vitamin E $(22.5 \mathrm{mg} / \mathrm{kg})$, and even with the expected prevention of the lipid oxidation in meat by vitamin E, the Cistus ladanifer resulted in a significant protection of the meat against lipid oxidation. In a more recent work, the partial replacement of dehydrated lucerne with $150 \mathrm{~g} / \mathrm{kg}$ DM of Cistus ladanifer in oil supplemented diets (50-60 g/ kg DM of soybean oil) composed by 1:1 forage and concentrate did not reduced the MDA levels in lamb meat [62]. In this experiment, all diets were also supplemented with vitamin E $(22.5 \mathrm{mg} / \mathrm{kg})$, which may have masked a possible beneficial of Cistus ladanifer on lipid stability. Differences in basal diets, levels and type of lipid supplement and inclusion of other antioxidant compounds in diets might have created a different antioxidant-pro-oxidant balance among experiments, leading to the inconsistent results on the antioxidant effect of the dietary Cistus ladanifer [75].

The inclusion of two different CT-rich woody species-Larrea divaricata $(125 \mathrm{~g} / \mathrm{kg}$ DM of leaves) and Acacia aroma (125 g/ kg DM of leaves) — in goat diets composed by forage and concentrate did not change the antioxidant activity (DPPH assay) and total phenols content in meat, but reduced the MDA levels in meat stored at $4{ }^{\circ} \mathrm{C}$ for 6 days, at $-18{ }^{\circ} \mathrm{C}$ for 30 days and at $26^{\circ} \mathrm{C}$ for $6 \mathrm{~h}$ [63]. Delgadillho-Puga et al. [64] also did not observed differences in milk antioxidant activity evaluated by DPPH assay in dairy goats fed a diet composed of forage:grain concentrate (60:40) containing increasing levels of Acacia farnesiana pods $(0,100,200$ and $300 \mathrm{~g} / \mathrm{kg} \mathrm{DM})$. On the other hand, when the FRAP and oxygen radical absorbance capacity (ORAC) assays were used, an increase of the antioxidant activity of milk was reported, reaching similar or higher values than those presented in the milk of goats fed exclusively on pasture. Increasing levels of total phenols in goats' milk with increasing amounts of Acacia farnesiana pods in diets was also observed; however, the catechin levels remained unchanged.

The impact of some native species on animal antioxidant status was evaluated by analyses of several antioxidant parameters in the erythrocytes, including enzymatic and non-enzymatic antioxidants and lipid peroxidation parameters. In cows, the dietary replacement of rice bran by dried and ground leaves of Ficus bengalensis ( $119 \mathrm{~g} / \mathrm{kg}$ in concentrate), a tanniferous native tree from the Indian Subcontinent [65], seems to enhance the animal antioxidant status, increasing the intracellular GSH and the activity of antioxidant enzymes SOD and CAT, while reducing the MDA levels and increasing the level of total thiol (T-SH) groups that act as intracellular antioxidants by scavenging free radicals through enzymatic reactions [65]. Similar results were also verified in lambs, when increasing levels of ground leaves of Ficus infectoria (evergreen tree abundant in northern parts of India) were included in their diets $(106,159$ and $212 \mathrm{~g} / \mathrm{kg}$ ) [66]. Inclusion of Ficus infectoria and Psidium guajava leaf mixture (70:30) in concentrate feed (100, 150 and $200 \mathrm{~g} / \mathrm{kg})$ supplied to lambs enhanced the erythrocytic antioxidant status, increasing the intracellular activity of SOD and CAT and the levels of GST, GSH and total and protein thiol (P-SH) [67]. Increased levels of GSH and SOD activity in the blood were also observed in goats that received oak leaves (Quercus electrophori) containing $3.35 \%$ of CT and $3.10 \%$ of HT, suggesting an improvement in the antioxidant status of those animals [68].

Forage legumes with high levels of CTs, such as sainfoin and high-tannin sorghum, were also evaluated in terms of their effectiveness to limit meat lipid oxidation when incorporated in ruminant diets. Feeding lambs with silages containing sainfoin improved the lipid oxidative stability of meat subjected to pro-oxidant conditions (cooking and incubation with pro-oxidant catalysts) compared to grass silages [69]. Consistently, Lobón et al. [70] reported lower levels of lipid oxidation from day 7 to day 14 of storage at $4{ }^{\circ} \mathrm{C}$ in meat of suckling lambs when dams grazed on a sainfoin pasture compared to meat of suckling lambs from dams fed a total mixed ration. The protective effect of high-tannin sorghum against lipid oxidation in meat was contradictory, reducing the MDA levels in vacuumpackaged beef, while increased the lipid oxidation during aerobic display of the beef 
(14 days at $4{ }^{\circ} \mathrm{C}$ ) [71]. In this work, the activity of antioxidant enzymes in muscle was not affected by high-tannin sorghum.

Differences in CT chemical structure and concentration in the diet, as well as the diversity of basal diets used and the presence of other bioactive compounds with antioxidant activity in the diet, can help to explain the inconsistent results on the antioxidant effect of CT-rich plants and by-products, either between different CT sources, or with the same CT source. It is also important to note that within each CT source type, the CT levels can be variable among experiments, since the biosynthesis of phenolic compounds, such as CTs, depends on several factors, including variety, plant/fruit development stage, environmental temperature and water availability [21,77-79]. Thus, the utilization of the same level of a certain plant or by-product may not correspond to an equal CT amount in the diet. Another important aspect when CTs is provided to animals through the inclusion of plants or by-products in diets is the presence of other antioxidant compounds in addition to CTs in the vegetable material, such as other phenolic compounds and vitamins, which makes it impossible to isolate the contribution of CTs to the antioxidant effect.

\subsection{Condensed Tannin Extracts}

Utilization of CT extracts allows a better understanding of the specific effect of dietary CTs on ruminant antioxidant status and oxidative stability of their products. Quebracho, mimosa and grape seed have been the main CT extracts applied in ruminant diets, as possible sources of antioxidants (Table 2).

The protective effect of dietary quebracho CTs against lipid oxidation was verified by Lobón et al. [80] in meat of suckling lambs when dams fed pasture or hay were supplemented with $300 \mathrm{~g} /$ head of concentrate containing $10 \%$ of quebracho. Conversely, the supplementation of fattening concentrate of the weaned lambs with $50 \mathrm{~g} / \mathrm{kg}$ of quebracho did not affect the MDA levels in meat over 14 days of storage [70]. No effect of dietary supplementation with quebracho on lamb meat lipid oxidation was also reported by Brogna et al. [81], when including $80 \mathrm{~g} / \mathrm{kg}$ of quebracho in lamb diets, and by Luciano et al. [82], who supplemented the barley-based concentrate with $89 \mathrm{~g} / \mathrm{kg}$ DM of quebracho. However, in this last study, Luciano et al. [82] also observed that supplementation of lamb diets with quebracho reduced the metmyoglobin formation and produced an improvement in the muscle antioxidant capacity evaluated using FRAP and TEAC assays and increased the concentration of total phenolic compounds in muscle [83]. Improvement of the liver overall antioxidant status by dietary supplementation with quebracho CT was also observed by López-Andrés et al. [84], who reported higher values of FRAP and total phenolic content in the liver of lambs fed a concentrate containing $64 \mathrm{~g} / \mathrm{kg}$ of quebracho in contrast to the control ones. In turn, Buccioni et al. [85] found that supplementation of concentrate with $52.8 \mathrm{~g} / \mathrm{kg}$ DM of quebracho was not able improve the oxidative status in lactating grazing ewes, when they determined the MDA levels in plasma of ewes fed CT-supplemented concentrate.

In lambs, the incorporation of $25 \mathrm{~g} / \mathrm{kg}$ DM of grape seed extract in a high-forage diet supplemented or not with a blend of vegetable oils (sunflower and linseed oils, 1:2(v/v)) reduced the MDA levels in meat stored for 3 and 7 days at $4{ }^{\circ} \mathrm{C}$ and subjected to lipid oxidation induction [59]. Consistently, $\mathrm{Mu}$ et al. [86] reported that the MDA content decreased linearly in lamb meat with increasing levels of grape seed extract $(0$, 20,30 and $40 \mathrm{mg} / \mathrm{kg}$ body weight/day) in the high-concentrate diet. Furthermore, the increasing levels of grape seed extract in the diet also resulted in a linear increase of the total antioxidant capacity and activity of the CAT, SOD and GPx4 in muscle [86]. Improvement of the total antioxidant capacity, evaluated in plasma by TEAC assay, was also reported by Gladine et al. [87] when grape seed extract was infused directly into rumen. Conversely, the plasma antioxidant activity (FRAP assay) of dairy goats and sheep was not affected by concentrate supplementation with grape seed extract (74 g/kg DM) [88]. Feeding lambs with concentrate diet supplemented with $50 \mathrm{mg} / \mathrm{kg}$ DM of grape seed extract also did not affect the MDA and metmyoglobin contents in meat packaged under high $\mathrm{O}_{2}$ atmosphere 
$\left(\mathrm{O}_{2}: \mathrm{CO}_{2}, 80: 20\right)$ and stored at $4{ }^{\circ} \mathrm{C}$ for 14 days [52]. Contents of MDA and protein carbonyl in PUFA $n-3$ enriched meat stored in a modified atmosphere $\left(\mathrm{O}_{2}: \mathrm{CO}_{2}, 70: 30\right)$ over 12 days at $4{ }^{\circ} \mathrm{C}$ was also not affected by supplementation of lamb diets with $900 \mathrm{mg}$ of red wine extract per $\mathrm{kg}$ of concentrate [89].

The efficacy of dietary supplementation with mimosa (Acacia mearnsii) CT extract to protect lamb meat against lipid oxidation was tested in two studies, where $40 \mathrm{~g} / \mathrm{kg}$ of mimosa extract was included in concentrate [90,91]. In both experiments the supplementation of diet with mimosa extract did not affect the MDA levels in raw meat stored at $4{ }^{\circ} \mathrm{C}$ over 7 days $[90,91]$, not even in meats subjected to pro-oxidant conditions (cooking and meat homogenate with pro-oxidant catalysts) [91]. However, the effect of mimosa CT extract on oxidation of myoglobin in meat was contradictory: one of these works reported the reduction of metmyoglobin formation [90], while the other showed that supplementation of diets with mimosa CT extract did not affect the myoglobin oxidation [91]. Lipid oxidation in salted and sun-dried meat from bulls fed an oil-supplemented $(42.5 \mathrm{~g} / \mathrm{kg}$ DM of soybean oil) diet composed of 40:60 forage and concentrate was also not affected by increasing levels of mimosa extract in the diets $(10,30$ and $50 \mathrm{~g} / \mathrm{kg} \mathrm{DM})$ [92]. Similar results were also found by Staerfl et al. [93], who reported that supplementation of maize silage with concentrate containing $141 \mathrm{~g} / \mathrm{kg}$ of mimosa extract did not improved the oxidative stability of perirenal fat of bulls. More recently, Avilla et al. [94] supplemented the diets of lactating dairy cows with increasing levels of Acacia mearnsii CT extract $(6.12,12.25 ; 18.42$ and $24.58 \mathrm{~g} / \mathrm{kg} \mathrm{DM})$ and found no differences in the MDA milk levels. However, they found increasing diene conjugates concentration, which indicates a greater lipid peroxidation, with increasing CT levels.

Although the results point to the effectiveness of CT extracts in improving the overall antioxidant status of ruminants and the oxidative stability of their products, the results are controversial, and for some CT extracts, antioxidant effect in ruminants have not yet been verified, as reported for the mimosa extracts. The inconsistent antioxidant effect in ruminants of the various CT extracts may be related to the chemical structure of CTs, once the CT structure differs markedly according to its origin [22,23]. Moreover, several other factors can contribute to inconsistent antioxidant effect of CT extracts, such as CT concentration in the diets, composition of basal diet, presence of pro- and antioxidant compounds, or other uncontrolled factors as environmental temperature and stress-inducing situations, that might create a different balance between antioxidant and pro-oxidant agents. In addition, the interpretation of results is hampered by the diversity of analytical techniques and standards used to quantify the CTs, and in some studies, such information is not displayed. The CT content in sources and diets has been quantified through butanol$\mathrm{HCl}[53,54,56,59-61,65,66]$ and vanillin $[71,72]$ assays and using different standards, such as cyanidin chloride, leucocyanidin, catechin, tannic acid or CT purified from the vegetal material under study (see footnotes of Tables 1 and 2). Some studies only reported the total tannins content, or the CT levels supplied by the manufacturer without identification of the procedures used for CT quantification, and in others, the CT levels in diets are not reported. The lack of information on the CT contents and the non-standardization of methodologies and standards used for quantification make comparisons between studies difficult.

If the occurrence of antioxidant compounds other than CTs can contribute to the antioxidant effect when CT-rich plants and by-products are used, the improvement in antioxidant status and oxidative stability observed by the inclusion of the CT extracts in principle are directly related to $\mathrm{CT}$ action. However, the mechanisms by which CTs are able to exert an antioxidant effect in ruminants are unclear. So, elucidation of the CT antioxidant mechanisms is a relevant topic that might be useful to understand the controversial results on the antioxidant effect of dietary CTs in ruminants, and to design effective antioxidant strategies for these species based on incorporation of the CT sources in their diets. 
Table 2. Antioxidant effect of utilization of condensed tannin extracts in ruminant diets.

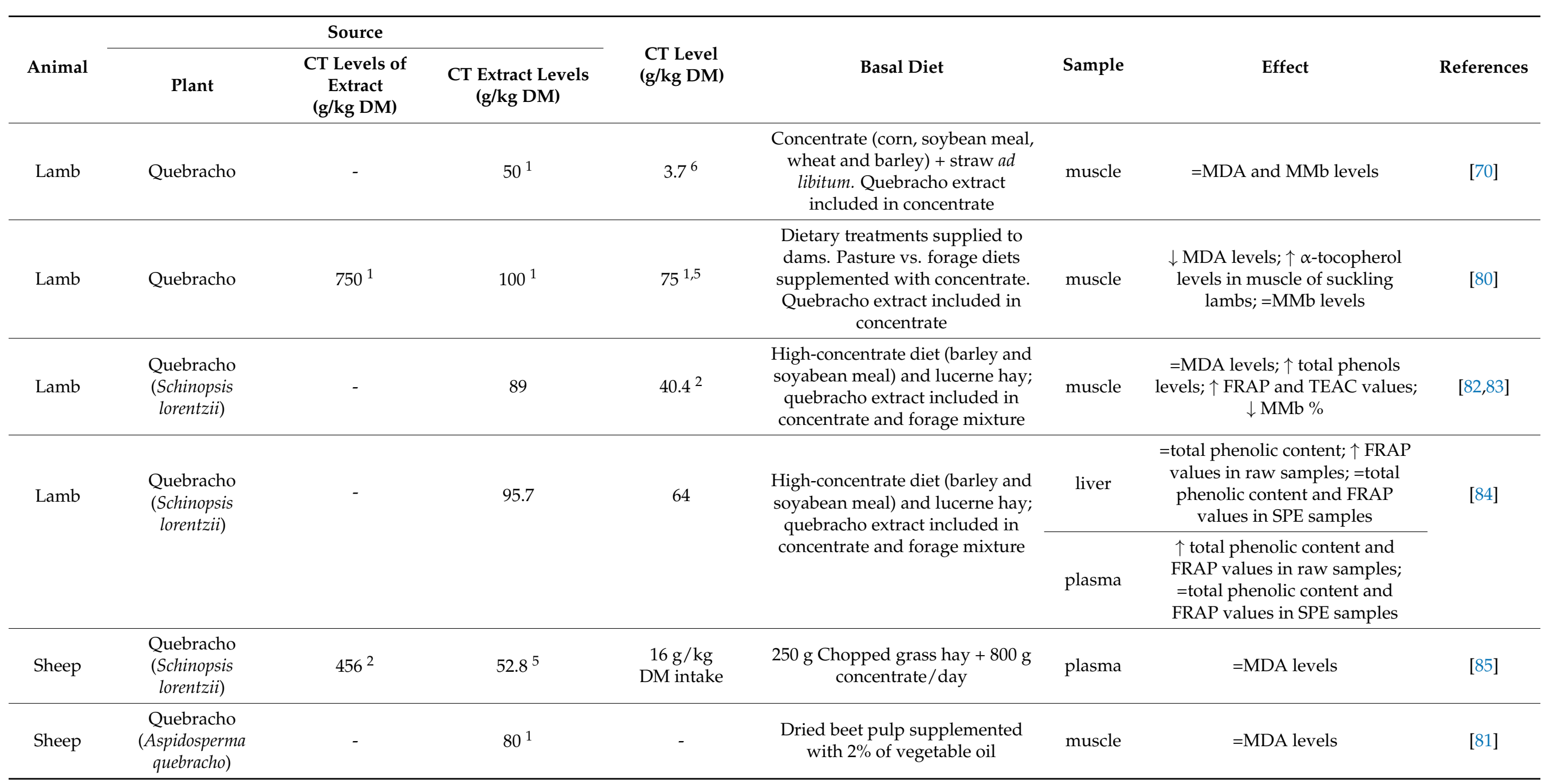


Table 2. Cont.

\begin{tabular}{|c|c|c|c|c|c|c|c|c|}
\hline \multirow[b]{2}{*}{ Animal } & \multicolumn{3}{|c|}{ Source } & \multirow[b]{2}{*}{$\begin{array}{l}\text { CT Level } \\
\text { (g/kg DM) }\end{array}$} & \multirow[b]{2}{*}{ Basal Diet } & \multirow[b]{2}{*}{ Sample } & \multirow[b]{2}{*}{ Effect } & \multirow[b]{2}{*}{ References } \\
\hline & Plant & $\begin{array}{l}\text { CT Levels of } \\
\text { Extract } \\
\text { (g/kg DM) }\end{array}$ & $\begin{array}{l}\text { CT Extract Levels } \\
\text { (g/kg DM) }\end{array}$ & & & & & \\
\hline Lamb & $\begin{array}{c}\text { Grape seed } \\
\text { (Vinis vitifera) }\end{array}$ & 950 & 25 & $14.1^{7}$ & $\begin{array}{c}\text { Dehydrated lucerne } \\
\text { supplemented with } 0 \text { or } 6 \% \text { of a } \\
\text { mixture of sunflower and linseed } \\
\text { oils }(1: 2, v / v)\end{array}$ & muscle & $\begin{array}{l}\downarrow \text { MDA levels after lipid } \\
\text { oxidation induction }\end{array}$ & [59] \\
\hline Lamb & Grape seed & - & $\begin{array}{c}\text { 10, } 20 \text { and } 40 \\
\mathrm{mg} / \mathrm{kg} \text { BW/day }\end{array}$ & - & $\begin{array}{l}\text { Total mixed feed with } \\
\text { concentrate (corn, soybean meal, } \\
\text { cottonseed meal, wheat bran): } \\
\text { forage (corn and millet straw) } \\
(70: 30)\end{array}$ & muscle & $\begin{array}{c}\uparrow \text { total antioxidant capacity, } \uparrow \\
\text { activity of CAT, SOD and GPx4; } \downarrow \\
\text { MDA levels }\end{array}$ & [86] \\
\hline Lamb & Grape seed & 413 & $\underset{\mathrm{DM}^{5}}{50 \mathrm{mg} \text { extract} / \mathrm{kg}}$ & - & $\begin{array}{l}\text { Barley straw and concentrate } \\
\text { (barley, soya and molasses) ad } \\
\text { libitum, grape seed extract } \\
\text { included in concentrate }\end{array}$ & muscle & $=$ MDA levels and $\mathrm{MMb} \%$; & [52] \\
\hline $\begin{array}{l}\text { Sheep } \\
\text { Goat }\end{array}$ & Grape seed & - & $74^{5}$ & $7.3-7.5^{4}$ & $\begin{array}{l}\text { Forage:concentrate:dried sugar } \\
\text { beet pulp (51:46:3), grape seed } \\
\text { included in concentrate }\end{array}$ & $\begin{array}{c}\text { milk } \\
\text { plasma }\end{array}$ & $\begin{array}{l}=\text { FRAP values in plasma; } \uparrow \text { total } \\
\text { phenol concentration in plasma } \\
\text { and milk }\end{array}$ & [88] \\
\hline Lamb & Red wine extract & - & $\begin{array}{l}900 \text { mg extract } / \mathrm{kg} \\
\text { feed }^{5}\end{array}$ & - & $\begin{array}{l}\text { Barley + concentrate (corn meal, } \\
\text { barley, wheat, soybean meal, } \\
\text { sunflower meal) supplemented } \\
\text { with extruded linseed and } \\
\text { deodorized fish oil; red wine } \\
\text { extract included in concentrate }\end{array}$ & muscle & $\begin{array}{c}=\text { MDA and protein carbonyl } \\
\text { levels; } \\
=\text { total phenols content }\end{array}$ & [89] \\
\hline Lamb & $\begin{array}{c}\text { Mimosa } \\
\text { (Acacia mearnsii) }\end{array}$ & - & $40^{1}$ & $22.3^{2}$ & $\begin{array}{l}\text { Concentrate (barley, wheat bran, } \\
\text { soybean meal, molasses): } \\
\text { dehydrated lucerne (85:15) }\end{array}$ & muscle & $=$ MDA levels $; \downarrow \mathrm{MMb} \%$ & [90] \\
\hline
\end{tabular}


Table 2. Cont.

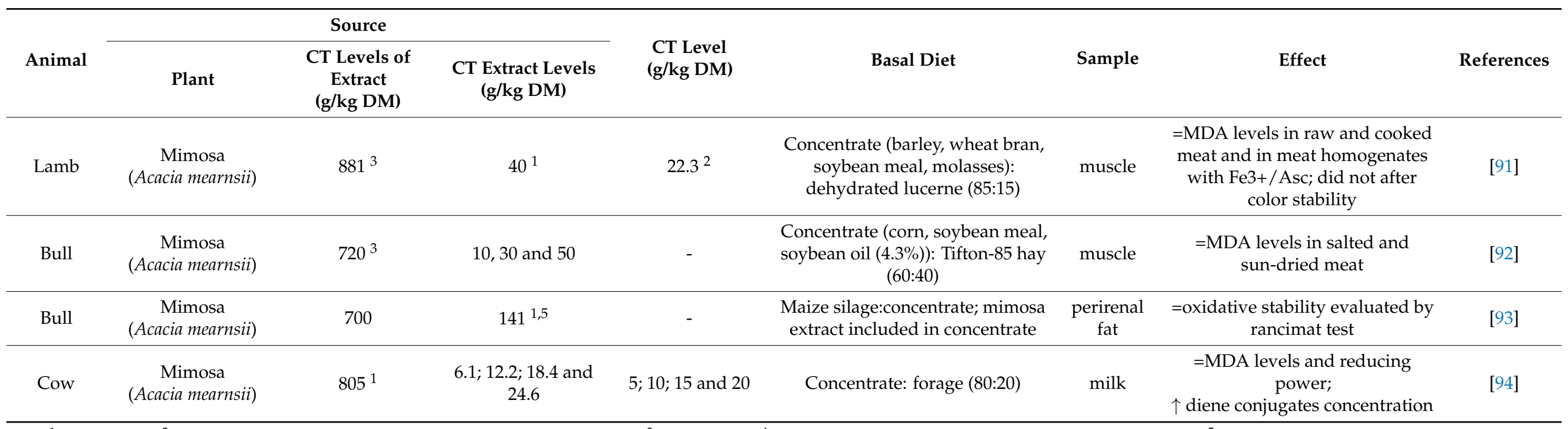

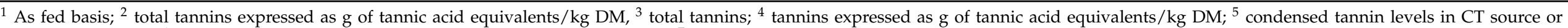

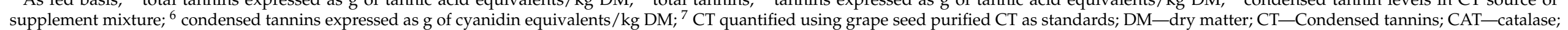

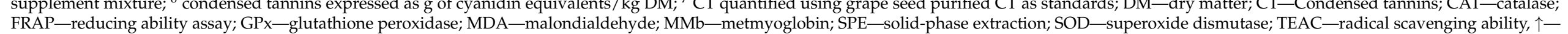
increase; $\downarrow$ - reduction 


\section{Condensed Tannins' Antioxidant Action Mechanisms}

As with other polyphenols, the antioxidant function of CTs involves diverse mechanisms, such as scavenging of free radicals, transition metals chelation and the inhibition of pro-oxidative enzymes [25]. Moreover, antioxidant synergies between exogenous phenolics and endogenous antioxidants have been reported, and it is known that CTs can interfere with the metabolism of other antioxidant compounds [95]. The antioxidant activity of CTs is well established in in vitro models, as well as when directly applied to food products. However, the mechanisms by which CTs can induce antioxidant activity in vivo are still unclear. Unlike other phenolic compounds with low molecular weight, the polymeric nature and high structural complexity of CTs limit their absorption into circulation and the direct antioxidant effect in living animal and post-mortem, making it more difficult to explain the mechanisms by which CTs has antioxidant effect in vivo. Several action mechanisms, involving direct and indirect mechanisms, seem to be possible, such as: (i) absorption of CTs or metabolites allowing direct action in animal body and tissues; (ii) antioxidant action in the gastrointestinal tract (GIT); and (iii) interaction with other antioxidant compounds and endogenous antioxidant system.

The presence of the CTs in circulation and deposition in tissues would allow a direct antioxidant action. However, the bioavailability (usually defined as the concentration of a given compound or its metabolites that reaches the systemic circulation [96]) of CTs depends highly on the degree of polymerization and molecular weight $[22,23]$. Condensed tannins are characterized by their polymeric nature and high molecular weight, which limit their bioavailability once only monomers and oligomers up to tetramers can be absorbed and transported via circulation to various organs $[23,97,98]$. Moreover, between monomers and oligomers that can be absorbed, there are differences in absorption rates, depending on the molecular weight, chemical structure and stereochemical configuration $[23,24,97]$. The flavan-3-ol monomers show different absorption rates according to chemical structure and stereochemical configuration, decreasing the absorption rate from $(-)$-epicatechin $>(+)-$ epicatechin $=(+)-$ catechin $>(-)-$ catechin [99]. In addition, the absorption rates of CT dimers, trimers and tetramers decrease with their increasing molecular size and number of hydrophilic hydroxyl groups [97]. Although the CT chemistry varies between plant sources, generally it is mainly composed of oligomers and polymers, and low molecular weight CTs are present in low concentrations [22,23]. So, the contribution of native CT monomers and small oligomers to generate antioxidant effects through their absorption may be limited.

The degradation of CTs into compounds with a lower degree of polymerization or even to monomers throughout the GIT would allow greater availability of absorbable compounds, but the CT metabolization in the GIT is still poorly understood. Despite the conflicting results, several reports have shown that CTs are not inert during transit through the GIT, instead they are subject to extensive biotransformation processes [23,98,100,101]. Along the GIT, there are conditions like gastric acidity and microorganisms that could promote CT changes. However, CTs are characterized by their high resistance to degradation induced by acid conditions and by most microorganisms [102], which can limit the CT transformation in the GIT. Results on CT degradation under acidic conditions are inconsistent. Degradation of procyanidin oligomers from cocoa and apple with the production of oligomers with a lower degree of polymerization and monomers was observed after in vitro incubations under acid conditions [103-105]. On the other hand, simulating the gastric conditions, Li et al. [106] observed only a slight decrease in the degree of polymerization of CTs from Choerospondias axillaris peels after incubation. Gültekin-Ozgüven et al. [105] reported that monomers and dimers from cocoa remained stable under acidic conditions. In humans, it was also demonstrated that cocoa CT remained quite stable during in vitro gastric digestion [107]. So, due to their high resistance to acidic conditions and low absorption in the small intestine, it is widely accepted that most of the CTs reaches the colon 
intact, where they are metabolized through the action of the intestinal microbiota with the production of various low molecular weight compounds that can be absorbed into the circulation $[97,102,108]$. The transformation of CTs by gut microbiota has been reviewed, with a wide variety of compounds reported to be generated, mainly aromatic acids and valerolactones, which can also contribute to the health effects of CTs $[23,97,98,102,108]$. Although CTs might undergo extensive metabolization during transit through the GIT, the presence of CT monomers, oligomers, and polymers in feces of animals that received CT sources [109-111] suggests that their biotransformation is incomplete [110].

The studies on the fate of CTs in the GIT have been performed mainly using in vitro models and in humans and animals such as rats and pigs [23,108], while in ruminants the literature available on CT metabolism throughout GIT is scarce. Recently, Quijada et al. [112] reported a large disappearance of CTs from sainfoin and hazelnut skin between feed and feces (61-85\%), suggesting that CTs may be structurally modified, degraded, or absorbed along the GIT. Consistently, the recovery of CTs in feces from sainfoin-fed cows was less than would be expected if the CTs remained inert throughout the GIT [40]. Moreover, a reduction of the mean degree of polymerization $(\mathrm{mDP})$ of $\mathrm{CTs}$ in the digestive tract was observed in these cows fed sainfoin [40]. Recently, Girard et al. [37] also reported that only $46 \%$ and $78 \%$ of CTs were recovered in the large intestine of the lambs fed sainfoin or birdsfoot trefoil silages, respectively. In both lambs fed sainfoin or birdsfoot trefoil silages, soluble CTs were detected in the digesta when the Acetone-HCl-butanol assay was used, but a large part of soluble PC and PD were not detected by UPLC-MS/MS analysis, suggesting the occurrence of chemical transformations of CTs in the digestive tract in compounds that could not be detected by the specific MS/MS method for analysis of PC and PD. Using ${ }^{14} \mathrm{C}$-labeled CTs, a substantial disappearance of CTs from sheep and goat gastrointestinal tracts was also identified $[113,114]$. Gladine et al. [87] reported the presence of epicatechins in the plasma of sheep that received grape peel and skin extract directly into the rumen. Considering the minor proportion of monomeric compounds in grape peel and skin extract, Gladine et al. [87] associated the presence of epicatechins in the plasma of sheep with the possible biodegradation of polymeric CTs by the ruminal microorganisms. Conversely, Makkar et al. $[115,116]$ could not demonstrate the degradation of CTs by rumen microorganisms. However, it could be hypothesized that CTs can also be metabolized in the rumen and in the intestine of ruminants, similarly to what happens in the colon of humans [37], and further studies using advanced techniques of CT analysis can help to elucidate the fate of CTs in the GIT of ruminants.

Condensed tannins are known for their ability to form complexes with various types of molecules, primarily with proteins and to a lesser extension with polysaccharides, nucleic acids and metal ions [117]. These complexes are generally unstable depending on numerous factors, including $\mathrm{pH}$, and the $\mathrm{pH}$ variation along the ruminants GIT defines the behavior of CTs. Condensed tannins form stable complexes with proteins under the rumen $\mathrm{pH}$ conditions ( $\mathrm{pH} 5.5$ to 7.0 ), releasing under the acid conditions of the abomasum $(\mathrm{pH}$ 2.5 to 3.5$)$, and in alkaline conditions of the distal small intestine $(\mathrm{pH} \approx 7.5)[118,119]$. So, the GIT conditions can conditionate the accessibility to $\mathrm{CTs}$ and, therefore, their reactivity and bioavailability.

Despite the conflicting results on CT metabolization and absorption, increasing evidence supports that CTs undergo transformation along the GIT. The discrepancy in these results can be attributed to several factors, such as type of CT (degree of polymerization, chemical structure), possible interactions with food/feed matrix [23], and animal species. Furthermore, methodologies that have been used over time to assess the concentration and composition CTs and their metabolites have different sensitivities, which may also help to explain the conflicting results.

Several studies reported an increase of the total phenolic content, determined using Folin-Ciocalteau reagent, in plasma, muscle and milk of ruminants fed diets contain CTs (shown in Tables 1 and 2), which could suggest a possible transfer of dietary CTs to plasma, muscle and milk. However, the Folin-Ciocalteau reagent is not specific to phenolic 
compounds and can react with other reducing agents [120], so these results should be interpreted with caution. Presence of CT monomers or small oligomers in plasma, muscle and milk of ruminants fed CT sources only was reported by Gladine et al. [87], who identified epicatechins in the plasma of sheep fed supplements with grape peel and skin extract. Conversely, no phenolic compounds were detected in liver and plasma of lambs supplemented with quebracho CT extract [84]. The level of catechins in milk also did not change when increasing levels of Acacia farnesiana were added to goats' diets [64].

Although the CTs in intact form or their metabolites can be absorbed and transported to organs by blood inducing beneficial effects, the great proportion of CTs and their metabolites that are excreted in feces is an indicator of their poor bioavailability [23]. So, the contribution of dietary CTs to animal antioxidant status and oxidative stability of products through absorption is probably very limited, although it cannot be excluded. Other action mechanisms can be involved in the antioxidant activity of CTs in vivo.

The gastrointestinal tract has been proposed as the main site of CTs' action, where they and/or their metabolites can directly exert several biological activities, as antioxidant activity. In the intestine, CTs can scavenge free radicals, chelate metals, and reduce lipid peroxidation and the production of lipid oxidation derivatives and toxic compounds, which could result in improvements of the animal's overall antioxidant status [121,122]. Moreover, several studies have shown that CTs are also able to protect other antioxidant molecules from oxidation, such as vitamins. This would increase the amounts of antioxidant compounds along the GIT, contributing to enhance the animal's antioxidant status [95]. Yamamoto et al. [123] reported the increase of vitamin E levels in the large intestine mucosa of rats fed green tea catechins. The effect of CTs on vitamin E levels does not appear to be limited to GIT alone and increases in vitamin E concentrations have been reported in tissues from animals fed CT sources. The inclusion of grape extract in rat diets increased the vitamin E content by $24 \%$ in the liver [124]. Furthermore, it has been reported that several phenolic compounds, including catechins and epicatechins, increase the vitamin E levels in the plasma and liver of rats [125]. Inclusion of $200 \mathrm{~g} / \mathrm{kg}$ DM of Cistus ladanifer in lamb diets also resulted in increased levels of $\alpha$-tocopherol in muscle [61]. Although Cistus ladanifer can be a source of vitamin E, other mechanisms that may be responsible for these higher levels of $\alpha$-tocopherol in muscle cannot be excluded. Various mechanisms by which phenolic compounds might induce such an increase have been hypothesized, such as by protecting vitamin $\mathrm{E}$ against oxidation, restoring the vitamin from oxidation, and inhibition of metabolism and enhancement of absorption [126].

Moreover, CTs are also able to protect other antioxidant compounds in addition to vitamin E, such as ascorbic acid [95]. Iglesias et al. [95] demonstrated the strong ability of grape CT to repair oxidized $\alpha$-tocopherol and to delay the ascorbic acid depletion in muscle tissues of fish. Regeneration of $\alpha$-tocopherol from tocoperoxyl radical was also observed by Facino et al. [127] by the addition of grape procyanidins to phosphatidylcholine liposomes and red blood cells. So, the interaction with other antioxidant compounds in GIT, increasing their availability for absorption or to exert antioxidant activity in GIT, or even the interaction of CTs that can be absorbed with other antioxidant compounds in circulation or deposited in tissues, are possible mechanisms by which CTs can exert antioxidant activity indirectly.

Moreover, it has also been shown that CTs' beneficial effects may be related to an ability to modulate the cell signaling pathways, thus affecting the expression of specific genes [22]. Supplementation of sheep diets with grape skin increases the gene expression of SOD in plasma [128]. More recently, Mu et al. [86] reported increased GPx4 and SOD mRNA abundance in longissimus dorsi muscle from lambs fed on grape seed CT. Higher antioxidant enzymes gene expression was also observed in human hepatoblastoma cells incubated with grape seed procyanidins [129]. Consistently, increased activity of antioxidant enzymes was observed in animals fed sources of CT, as presented in previous Sections 3.1 and 3.2. Increased transcription factor Nrf2 (nuclear factor erythroid 2-related factor 2) was observed in the muscle of lambs fed diets containing wine grape pomace [49] 
or grape seed CT extract [86]. Nrf2 is a major regulator of antioxidant protective genes, regulating the expression of proteins involved in the antioxidant defense system [130]. The Nrf2 pathway is activated by oxidative stress (excessive levels of ROS), but also by the presence of electrophilic compounds $[130,131]$. It is reported that some polyphenolic compounds are able to induce endogenous antioxidant defense mechanisms by modulating Nrf2 [130-134]. Among many other phenolic compounds, epicatechin and catechin have already been described as capable of activating the Nrf2 pathway [133]. Despite the poor bioavailability of CTs, the increased expression and activity of antioxidant enzymes and transcription factor Nrf2 observed in ruminants fed CT sources suggest that activation of cell signaling pathways may be another mechanism by which CTs can improve the antioxidant response in living animals.

\section{Conclusions}

The results showed that inclusion of CT-plants and plant extracts in ruminant diets can improve the animal antioxidant status and produce edible products with better oxidative stability. However, the antioxidant effect of dietary CT sources in ruminants has not been proven in all works, which can be due to several factors, such as CT chemical structure and concentration in the diets, composition of basal diet, presence of pro- and antioxidant compounds, or other uncontrolled factors that might create different balance between antioxidant and pro-oxidant agents.

Evidence supports that the antioxidant effects of CTs, which are observed both in living animals and post-mortem by preventing oxidative damage in products, may be due to multiple mechanisms of action, which could occur in an integrated and synergic way. The direct antioxidant effect, which implies the absorption of CTs or their metabolites and presence in circulation and tissues, probably is not the most relevant CT antioxidant mechanism considering the poor bioavailability of CTs. However, this mechanism cannot be excluded and can contribute to overall antioxidant status when CT sources contain or originate higher levels of absorbable CTs. The antioxidant action of CTs in the GIT is the most consensual method, which can also occur in different ways, reducing oxidation reactions and protecting other antioxidant compounds. Interaction with other enzymatic and non-enzymatic components of the antioxidant system seems to be another possibility by which CTs can exert antioxidant activity. In addition to other factors, the chemical structure of CTs seems to be an important factor in determining the antioxidant action mechanisms of CTs in vivo, so the way CTs exert antioxidant activity and its effectiveness probably depend on the CT's origin. However, the chemical structure of several CT sources used in animal nutrition is poorly characterized, and their characterization should be improved. In addition to better knowledge of the chemistry of each CT source, it is important to carry out further studies in ruminants to understand the action mechanism by which each CT source exerts antioxidant activity in living animals and in their products, which will allow design of effective antioxidant strategies based on the application of CT sources in diets.

Author Contributions: Conceptualization, D.S. and E.J.; writing—original draft preparation, D.S. and E.J.; writing - review and editing, D.S., E.J. and R.J.B.B.; supervision, E.J. and R.J.B.B. All authors have read and agreed to the published version of the manuscript.

Funding: This research was funded by the Fundação para a Ciência e Tecnologia (FCT) through research grants to D.S. (SFRH/BD/145814/2019) and the projects UIDB/00276/2020 from Centre for Interdisciplinary Research in Animal Health, Faculty of Veterinary Medicine, University of Lisbon and UIDB/05183/2020 from MED-Mediterranean Institute for Agriculture, Environment and Development; and by the Alentejo2020 program for financial support to the project "CistusRumenSustainable use of Rockrose (Cistus ladanifer L.) in small ruminants-Increase of the competitiveness and reduction of the environmental impact" (ALT20-03-0145-FEDER-000023) co-funded by European Regional Development Fund.

Conflicts of Interest: The authors declare no conflict of interest. 


\section{References}

1. Miller, J.K.; Brzezinska-Slebodzinska, E.; Madsen, F.C. Oxidative stress, antioxidants, and animal function. J. Dairy Sci. 1993, 76, 2812-2823. [CrossRef]

2. Surai, P.F.; Kochish, I.I.; Fisinin, V.I.; Juniper, D.T. Revisiting oxidative stress and the use of organic selenium in dairy cow nutrition. Animals 2019, 9, 462. [CrossRef] [PubMed]

3. Lushchak, V.I. Free radicals, reactive oxygen species, oxidative stress and its classification. Chem.-Biol. Interact. 2014, 224, 164-175. [CrossRef] [PubMed]

4. Sies, H. On the history of oxidative stress: Concept and some aspects of current development. Curr. Opin. Toxicol. 2018, 7, 122-126. [CrossRef]

5. Morrissey, P.A.; Sheehy, P.J.A.; Galvin, K.; Kerry, J.P.; Buckley, D.J. Lipid stability in meat and meat products. Meat Sci. 1998, 49, S73-S86. [CrossRef]

6. Hess, B.W.; Moss, G.E.; Rule, D.C. A decade of developments in the area of fat supplementation research with beef cattle and sheep. J. Anim. Sci. 2008, 86, E188-E204. [CrossRef]

7. Bessa, R.J.B.; Alves, S.P.; Santos-Silva, J. Constraints and potentials for the nutritional modulation of the fatty acid composition of ruminant meat. Eur. J. Lipid Sci. Technol. 2015, 117, 1325-1344. [CrossRef]

8. Shingfield, K.J.; Bonnet, M.; Scollan, N.D. Recent developments in altering the fatty acid composition of ruminant-derived foods. Animal 2013, 7, 132-162. [CrossRef]

9. Guo, Z.; Gao, S.; Ouyang, J.; Ma, L.; Bu, D. Impacts of heat stress-induced oxidative stress on the milk protein biosynthesis of dairy cows. Animals 2021, 11, 726. [CrossRef]

10. Deters, E.L.; Hansen, S.L. Invited Review: Linking road transportation with oxidative stress in cattle and other species. Appl. Anim. Sci. 2020, 36, 183-200. [CrossRef]

11. Puppel, K.; Kapusta, A.; Kuczyńska, B. The etiology of oxidative stress in the various species of animals, a review. J. Sci. Food Agric. 2015, 95, 2179-2184. [CrossRef] [PubMed]

12. Rahal, A.; Kumar, A.; Singh, V.; Yadav, B.; Tiwari, R.; Chakraborty, S.; Dhama, K. Oxidative stress, prooxidants, and antioxidants: The Interplay. BioMed Res. Int. 2014, 2014, 761264. [CrossRef] [PubMed]

13. Papuc, C.; Goran, G.V.; Predescu, C.N.; Nicorescu, V. Mechanisms of oxidative processes in meat and toxicity induced by postprandial degradation products: A review. Compr. Rev. Food Sci. Food Saf. 2017, 16, 96-123. [CrossRef]

14. Domínguez, R.; Pateiro, M.; Gagaoua, M.; Barba, F.J.; Zhang, W.; Lorenzo, J.M. A comprehensive review on lipid oxidation in meat and meat products. Antioxidants 2019, 8, 429. [CrossRef]

15. Samples, S. Oxidation and antioxidants in fish and meat from farm to fork. In Food Industry; Muzzalupo, M., Ed.; IntechOpen: London, UK, 2013. [CrossRef]

16. Jacobsen, C. Some strategies for the stabilization of long chain n-3 PUFA-enriched foods: A Review. Eur. J. Lipid Sci. Technol. 2015, 117, 1853-1866. [CrossRef]

17. Secci, G.; Parisi, G. From farm to fork: Lipid oxidation in fish products. A review. Ital. J. Anim. Sci. 2016, 15, 124-136. [CrossRef]

18. Aguilar, T.A.F.; Navarro, B.C.H.; Pérez, J.A.M. Endogenous antioxidants: A review of their role in oxidative stress. In The Transcription Factor Nrf2; Navarro, B.C.H., Ed.; IntechOpen: London, UK, 2016. [CrossRef]

19. Salami, S.A.; Guinguina, A.; Agboola, J.O.; Omede, A.A.; Agbonlahor, E.M.; Tayyab, U. Review: In vivo and postmortem effects of feed antioxidants in livestock: A review of the implications on authorization of antioxidant feed additives. Animal 2016, 10, 1375-1390. [CrossRef]

20. Huang, Q.; Liu, X.; Zhao, G.; Hu, T.; Wang, Y. Potential and challenges of tannins as an alternative to in-feed antibiotics for farm animal production. Anim. Nutr. 2018, 4, 137-150. [CrossRef]

21. Rauf, A.; Imran, M.; Abu-Izneid, T.; Iahtisham-Ul-Haq; Patel, S.; Pan, X.; Naz, S.; Silva, A.S.; Saeed, F.; Rasul Suleria, H.A. Proanthocyanidins: A comprehensive review. Biomed. Pharmacother. 2019, 116, 108999. [CrossRef]

22. Unusan, N. Proanthocyanidins in grape seeds: An updated review of their health benefits and potential uses in the food industry. J. Funct. Foods 2020, 67, 103861. [CrossRef]

23. Tao, W.; Zhang, Y.; Shen, X.; Cao, Y.; Shi, J.; Ye, X.; Chen, S. Rethinking the mechanism of the health benefits of proanthocyanidins: Absorption, metabolism, and interaction with gut microbiota. Compr. Rev. Food Sci. Food Saf. 2019, 18, 971-985. [CrossRef]

24. Yang, L.; Xian, D.; Xiong, X.; Lai, R.; Song, J.; Zhong, J. Proanthocyanidins against oxidative stress: From molecular mechanisms to clinical applications. BioMed Res. Int. 2018, 2018, 8584136. [CrossRef]

25. Koleckar, V.; Kubikova, K.; Rehakova, Z.; Kuca, K.; Jun, D.; Jahodar, L.; Opletal, L. Condensed and hydrolysable tannins as antioxidants influencing the health. Mini-Rev. Med. Chem. 2008, 8, 436-447. [CrossRef] [PubMed]

26. Jerónimo, E.; Pinheiro, C.; Lamy, E.; Dentinho, M.T.; Sales-Baptista, E.; Lopes, O.; Capela e Silva, F. Tannins in ruminant nutritionImpact on animal performance and quality of edible products. In Tannins: Biochemistry, Food Sources and Nutritional Properties; Nova Science Publishers: Hauppauge, NY, USA, 2016; pp. 121-168. ISBN 978-1-63484-150-4.

27. Piluzza, G.; Sulas, L.; Bullitta, S. Tannins in forage plants and their role in animal husbandry and environmental sustainability: A review. Grass Forage Sci. 2014, 69, 32-48. [CrossRef]

28. Waghorn, G. Beneficial and detrimental effects of dietary condensed tannins for sustainable sheep and goat production-Progress and challenges. Anim. Feed. Sci. Technol. 2008, 147, 116-139. [CrossRef] 
29. Caprarulo, V.; Giromini, C.; Rossi, L. Review: Chestnut and quebracho tannins in pig nutrition: The effects on performance and intestinal health. Animal 2021, 15, 100064. [CrossRef]

30. Zhang, Y.; Zhou, X.; Tao, W.; Li, L.; Wei, C.; Duan, J.; Chen, S.; Ye, X. Antioxidant and antiproliferative activities of proanthocyanidins from Chinese bayberry (Myrica Rubra Sieb. et Zucc.) leaves. J. Funct. Foods 2016, 27, 645-654. [CrossRef]

31. Hagerman, A.E.; Riedl, K.M.; Jones, G.A.; Sovik, K.N.; Ritchard, N.T.; Hartzfeld, P.W.; Riechel, T.L. High molecular weight plant polyphenolics (tannins) as biological antioxidants. J. Agric. Food Chem. 1998, 46, 1887-1892. [CrossRef]

32. Beninger, C.W.; Hosfield, G.L. Antioxidant activity of extracts, condensed tannin fractions, and pure flavonoids from Phaseolus vulgaris L. seed coat color genotypes. J. Agric. Food Chem. 2003, 51, 7879-7883. [CrossRef]

33. Serra, V.; Salvatori, G.; Pastorelli, G. Dietary polyphenol supplementation in food producing animals: Effects on the quality of derived products. Animals 2021, 11, 401. [CrossRef]

34. Lorenzo, J.M.; González-Rodríguez, R.M.; Sánchez, M.; Amado, I.R.; Franco, D. Effects of natural (grape seed and chestnut extract) and synthetic antioxidants (Buthylatedhydroxytoluene, BHT) on the physical, chemical, microbiological and sensory characteristics of dry cured sausage "Chorizo". Food Res. Int. 2013, 54, 611-620. [CrossRef]

35. Singh, A.P.; Kumar, S. Applications of tannins in industry. In Tannins-Structural Properties, Biological Properties and Current Knowledge; Aires, A., Ed.; IntechOpen: London, UK, 2019. [CrossRef]

36. Shrestha, S.; Zhang, W.; Smid, S.D. Phlorotannins: A review on biosynthesis, chemistry and bioactivity. Food Biosci. 2021, 39, 100832. [CrossRef]

37. Girard, M.; Lehtimäki, A.; Bee, G.; Dohme-Meier, F.; Karonen, M.; Salminen, J.-P. Changes in feed proanthocyanidin profiles during silage production and digestion by lamb. Molecules 2020, 25, 5887. [CrossRef]

38. Khanbabaee, K.; van Ree, T. Tannins: Classification and definition. Nat. Prod. Rep. 2001, 18, 641-649. [CrossRef] [PubMed]

39. Zeller, W.E. Activity, purification, and analysis of condensed tannins: Current state of affairs and future endeavors. Crop. Sci. 2019, 59, 886-904. [CrossRef]

40. Desrues, O.; Mueller-Harvey, I.; Pellikaan, W.F.; Enemark, H.L.; Thamsborg, S.M. Condensed tannins in the gastrointestinal tract of cattle after sainfoin (Onobrychis viciifolia) intake and their possible relationship with anthelmintic effects. J. Agric. Food Chem. 2017, 65, 1420-1427. [CrossRef] [PubMed]

41. Klongsiriwet, C.; Quijada, J.; Williams, A.R.; Mueller-Harvey, I.; Williamson, E.M.; Hoste, H. Synergistic Inhibition of haemonchus contortus exsheathment by flavonoid monomers and condensed tannins. Int. J. Parasitol. Drugs Drug Resist. 2015, 5, 127-134. [CrossRef]

42. Zhou, H.-C.; Tam, N.F.; Lin, Y.-M.; Ding, Z.-H.; Chai, W.-M.; Wei, S.-D. Relationships between degree of polymerization and antioxidant activities: A study on proanthocyanidins from the leaves of a medicinal mangrove plant Ceriops tagal. PLoS ONE 2014, 9, e107606. [CrossRef]

43. Zhou, H.-C.; Lin, Y.-M.; Li, Y.-Y.; Li, M.; Wei, S.-D.; Chai, W.-M.; Tam, N.F. Antioxidant properties of polymeric proanthocyanidins from fruit stones and pericarps of Litchi chinensis sonn. Food Res. Int. 2011, 44, 613-620. [CrossRef]

44. Es-Safi, N.-E.; Guyot, S.; Ducrot, P.-H. NMR, ESI/MS, and MALDI-TOF/MS analysis of pear juice polymeric proanthocyanidins with potent free radical scavenging activity. J. Agric. Food Chem. 2006, 54, 6969-6977. [CrossRef]

45. Frutos, P.; Hervás, G.; Natalello, A.; Luciano, G.; Fondevila, M.; Priolo, A.; Toral, P.G. Ability of tannins to modulate ruminal lipid metabolism and milk and meat fatty acid profiles. Anim. Feed. Sci. Technol. 2020, 269, 114623. [CrossRef]

46. Makkar, H.P.S.; Francis, G.; Becker, K. Bioactivity of phytochemicals in some lesser-known plants and their effects and potential applications in livestock and aquaculture production systems. Animal 2007, 1, 1371-1391. [CrossRef] [PubMed]

47. Vasta, V.; Luciano, G. The effects of dietary consumption of plants secondary compounds on small ruminants' products quality. Small Rumin. Res. 2011, 101, 150-159. [CrossRef]

48. Mueller-Harvey, I.; Bee, G.; Dohme-Meier, F.; Hoste, H.; Karonen, M.; Kölliker, R.; Lüscher, A.; Niderkorn, V.; Pellikaan, W.F.; Salminen, J.-P.; et al. Benefits of condensed tannins in forage legumes fed to ruminants: Importance of structure, concentration, and diet composition. Crop. Sci. 2019, 59, 861-885. [CrossRef]

49. Zhao, J.X.; Li, Q.; Zhang, R.X.; Liu, W.Z.; Ren, Y.S.; Zhang, C.X.; Zhang, J.X. Effect of dietary grape pomace on growth performance, meat quality and antioxidant activity in ram lambs. Anim. Feed. Sci. Technol. 2018, 236, 76-85. [CrossRef]

50. Zhao, J.; Jin, Y.; Du, M.; Liu, W.; Ren, Y.; Zhang, C.; Zhang, J. The effect of dietary grape pomace supplementation on epididymal sperm quality and testicular antioxidant ability in ram lambs. Theriogenology 2017, 97, 50-56. [CrossRef] [PubMed]

51. Vieira, C.; Guerra-Rivas, C.; Martínez, B.; Rubio, B.; Manso, T. Effects of grape pomace supplementation on the diet of lactating ewes as compared to vitamin E on the meat shelf life of suckling lambs. Meat Sci. 2021, 184, 108666. [CrossRef]

52. Guerra-Rivas, C.; Vieira, C.; Rubio, B.; Martínez, B.; Gallardo, B.; Mantecón, A.R.; Lavín, P.; Manso, T. Effects of grape pomace in growing lamb diets compared with vitamin E and grape seed extract on meat shelf life. Meat Sci. 2016, 116, 221-229. [CrossRef]

53. Chikwanha, O.C.; Moelich, E.; Gouws, P.; Muchenje, V.; Nolte, J.V.E.; Dugan, M.E.R.; Mapiye, C. Effects of feeding increasing levels of grape (Vitis vinifera Cv. Pinotage) pomace on lamb shelf-life and eating quality. Meat Sci. 2019, 157, 107887. [CrossRef]

54. Tayengwa, T.; Chikwanha, O.C.; Gouws, P.; Dugan, M.E.R.; Mutsvangwa, T.; Mapiye, C. Dietary citrus pulp and grape pomace as potential natural preservatives for extending beef shelf life. Meat Sci. 2020, 162, 108029. [CrossRef]

55. Santos, N.W.; Santos, G.T.D.; Silva-Kazama, D.C.; Grande, P.A.; Pintro, P.M.; de Marchi, F.E.; Jobim, C.C.; Petit, H.V. Production, composition and antioxidants in milk of dairy cows fed diets containing soybean oil and grape residue silage. Livest. Sci. 2014, 159, 37-45. [CrossRef] 
56. Gravador, R.S.; Luciano, G.; Jongberg, S.; Bognanno, M.; Scerra, M.; Andersen, M.L.; Lund, M.N.; Priolo, A. Fatty acids and oxidative stability of meat from lambs fed carob-containing diets. Food Chem. 2015, 182, 27-34. [CrossRef] [PubMed]

57. Lee, J.H.; Min, B.R.; Lemma, B.B. Quality characteristics of goat meat as influenced by condensed tannins-containing pine bark. Small Rumin. Res. 2017, 146, 28-32. [CrossRef]

58. Kafle, D.; Lee, J.H.; Min, B.R.; Kouakou, B. Carcass and meat quality of goats supplemented with tannin-rich peanut skin. J. Agric. Food Res. 2021, 5, 100159. [CrossRef]

59. Jerónimo, E.; Alfaia, C.M.M.; Alves, S.P.; Dentinho, M.T.P.; Prates, J.A.M.; Vasta, V.; Santos-Silva, J.; Bessa, R.J.B. Effect of dietary grape seed extract and Cistus ladanifer L. in combination with vegetable oil supplementation on lamb meat quality. Meat Sci. 2012, 92, 841-847. [CrossRef]

60. Francisco, A.; Dentinho, M.T.; Alves, S.P.; Portugal, P.V.; Fernandes, F.; Sengo, S.; Jerónimo, E.; Oliveira, M.A.; Costa, P.; Sequeira, A.; et al. Growth performance, carcass and meat quality of lambs supplemented with increasing levels of a tanniferous bush (Cistus ladanifer L.) and vegetable oils. Meat Sci. 2015, 100, 275-282. [CrossRef]

61. Jerónimo, E.; Soldado, D.; Sengo, S.; Francisco, A.; Fernandes, F.; Portugal, A.P.V.; Alves, S.P.; Santos-Silva, J.; Bessa, R.J.B. Increasing the $\alpha$-tocopherol content and lipid oxidative stability of meat through dietary Cistus ladanifer L. in lamb fed increasing levels of polyunsaturated fatty acid rich vegetable oils. Meat Sci. 2020, 164, 108092. [CrossRef]

62. Francisco, A.; Alves, S.P.; Portugal, P.V.; Dentinho, M.T.; Jerónimo, E.; Sengo, S.; Almeida, J.; Bressan, M.C.; Pires, V.M.R.; Alfaia, C.M.; et al. Effects of dietary inclusion of citrus pulp and rockrose soft stems and leaves on lamb meat quality and fatty acid composition. Animal 2018, 12, 872-881. [CrossRef]

63. García, E.M.; López, A.; Zimerman, M.; Hernández, O.; Arroquy, J.I.; Nazareno, M.A. Enhanced oxidative stability of meat by including tannin-rich leaves of woody plants in goat diet. Asian-Australas J. Anim. Sci. 2019, 32, 1439-1447. [CrossRef]

64. Delgadillo-Puga, C.; Cuchillo-Hilario, M.; León-Ortiz, L.; Ramírez-Rodríguez, A.; Cabiddu, A.; Navarro-Ocaña, A.; MoralesRomero, A.M.; Medina-Campos, O.N.; Pedraza-Chaverri, J. Goats' Feeding Supplementation with Acacia Farnesiana Pods and Their Relationship with Milk Composition: Fatty Acids, Polyphenols, and Antioxidant Activity. Animals 2019, 9, 515. [CrossRef]

65. Dey, A.; De, P.S. Influence of Condensed Tannins from Ficus Bengalensis Leaves on Feed Utilization, Milk Production and Antioxidant Status of Crossbred Cows. Asian-Australas. J. Anim. Sci. 2014, 27, 342-348. [CrossRef]

66. Dey, A.; Dutta, N.; Pattanaik, A.K.; Sharma, K. Antioxidant status, metabolic profile and immune response of lambs supplemented with tannin tich Ficus infectoria leaf meal. Jpn. J. Vet. Res. 2015, 63, 15-24.

67. Pathak, A.K.P.; Dutta, N.; Pattanaik, A.K.; Sharma, K.; Banerjee, P.S.; Goswami, T.K. The effect of condensed tannin supplementation through Ficus infectoria and Psidium guajava leaf meal mixture on erythrocytic antioxidant status, immune response and gastrointestinal nematodes in lambs (Ovis aries). Vet. Arh. 2017, 87, 139-156.

68. Chaurasiya, A.; Tamboli, P.; Chaurasiya, P.; Nehra, A.; Sahoo, B.; Kuriyal, A.; Sankar, M. Effect of feeding tannin rich oak (Quercus leucotrichophora) leaves on immunological parameters, antioxidant status and microbial nitrogen supply of parasitic infected goats in Kumaon hills. Int. J. Curr. Microbiol. Appl. Sci. 2018, 7, 455-465. [CrossRef]

69. Luciano, G.; Natalello, A.; Mattioli, S.; Pauselli, M.; Sebastiani, B.; Niderkorn, V.; Copani, G.; Benhissi, H.; Amanpour, A.; Valenti, B. Feeding lambs with silage mixtures of grass, sainfoin and red clover improves meat oxidative stability under high oxidative challenge. Meat Sci. 2019, 156, 59-67. [CrossRef] [PubMed]

70. Lobón, S.; Blanco, M.; Sanz, A.; Ripoll, G.; Bertolín, J.R.; Joy, M. Meat quality of light lambs is more affected by the dam's feeding system during lactation than by the inclusion of quebracho in the fattening concentrate. J. Anim. Sci. 2017, 95, 4998-5011. [CrossRef] [PubMed]

71. Larraín, R.E.; Schaefer, D.M.; Richards, M.P.; Reed, J.D. Finishing steers with diets based on corn, high-tannin sorghum or a mix of both: Color and lipid oxidation in beef. Meat Sci. 2008, 79, 656-665. [CrossRef]

72. Zhong, R.Z.; Fang, Y.; Wang, Y.Q.; Sun, H.X.; Zhou, D.W. Effects of substituting finely ground sorghum for finely ground corn on feed digestion and meat quality in lambs infected with Haemonchus contortus. Anim. Feed. Sci. Technol. 2016, 211, 31-40. [CrossRef]

73. Vasta, V.; Nudda, A.; Cannas, A.; Lanza, M.; Priolo, A. Alternative feed resources and their effects on the quality of meat and milk from small ruminants. Anim. Feed. Sci. Technol. 2008, 147, 223-246. [CrossRef]

74. Rodríguez-Solana, R.; Romano, A.; Moreno-Rojas, J.M. Carob pulp: A nutritional and functional by-product worldwide spread in the formulation of different food products and beverages. A Review. Processes 2021, 9, 1146. [CrossRef]

75. Jerónimo, E.; Dentinho, M.T.; Guerreiro, O.; Francisco, A.; Soldado, D.; Alves, S.P.; Santos-Silva, J.; Bessa, R.J.B. Cistus ladanifer L. in ruminant diets-A sustainable approach to improve the feed nutritional value and the quality of edible products. In Advances in Animal Health, Medicine and Production; Springer International Publishing AG: Cham, Switzerland, 2020; pp. 128-160. ISBN 978-3-030-61980-0.

76. Mercier, Y.; Gatellier, P.; Renerre, M. Lipid and protein oxidation in vitro, and antioxidant potential in meat from charolais cows finished on pasture or mixed diet. Meat Sci. 2004, 66, 467-473. [CrossRef]

77. Mangan, J.L. Nutritional effects of tannins in animal feeds. Nutr. Res. Rev. 1988, 1, 209-231. [CrossRef] [PubMed]

78. Skogsmyr, I.; Fagerström, T. The cost of anti-herbivory defence: An evaluation of some ecological and physiological factors. Oikos 1992, 64, 451-457. [CrossRef]

79. Guerreiro, O.; Dentinho, M.T.P.; Moreira, O.C.; Guerra, A.R.; Ramos, P.A.B.; Bessa, R.J.B.; Duarte, M.F.; Jerónimo, E. Potential of Cistus ladanifer L. (rockrose) in small ruminant diets-Effect of season and plant age on chemical composition, in vitro digestibility and antioxidant activity. Grass Forage Sci. 2016, 71, 437-447. [CrossRef] 
80. Lobón, S.; Sanz, A.; Blanco, M.; Ripoll, G.; Joy, M. The type of forage and condensed tannins in dams' diet: Influence on meat shelf life of their suckling lambs. Small Rumin. Res. 2017, 154, 115-122. [CrossRef]

81. Brogna, D.M.R.; Tansawat, R.; Cornforth, D.; Ward, R.; Bella, M.; Luciano, G.; Priolo, A.; Villalba, J. The quality of meat from sheep treated with tannin- and saponin-based remedies as a natural strategy for parasite control. Meat Sci. 2014, 96, 744-749. [CrossRef] [PubMed]

82. Luciano, G.; Monahan, F.J.; Vasta, V.; Biondi, L.; Lanza, M.; Priolo, A. Dietary tannins improve lamb meat colour stability. Meat Sci. 2009, 81, 120-125. [CrossRef]

83. Luciano, G.; Vasta, V.; Monahan, F.J.; López-Andrés, P.; Biondi, L.; Lanza, M.; Priolo, A. Antioxidant status, colour stability and myoglobin resistance to oxidation of Longissimus dorsi muscle from lambs fed a tannin-containing diet. Food Chem. 2011, 124, 1036-1042. [CrossRef]

84. López-Andrés, P.; Luciano, G.; Vasta, V.; Gibson, T.M.; Biondi, L.; Priolo, A.; Mueller-Harvey, I. Dietary quebracho tannins are not absorbed, but increase the antioxidant capacity of liver and plasma in sheep. Br. J. Nutr. 2013, 110, 632-639. [CrossRef]

85. Buccioni, A.; Pauselli, M.; Minieri, S.; Roscini, V.; Mannelli, F.; Rapaccini, S.; Lupi, P.; Conte, G.; Serra, A.; Cappucci, A.; et al. Chestnut or quebracho tannins in the diet of grazing ewes supplemented with soybean oil: Effects on animal performances, blood parameters and fatty acid composition of plasma and milk lipids. Small Rumin. Res. 2017, 153, 23-30. [CrossRef]

86. Mu, C.; Yang, W.; Wang, P.; Zhao, J.; Hao, X.; Zhang, J. Effects of high-concentrate diet supplemented with grape seed proanthocyanidins on growth performance, liver function, meat quality, and antioxidant activity in finishing lambs. Anim. Feed. Sci. Technol. 2020, 266, 114518. [CrossRef]

87. Gladine, C.; Rock, E.; Morand, C.; Bauchart, D.; Durand, D. Bioavailability and antioxidant capacity of plant extracts rich in polyphenols, given as a single acute dose, in sheep made highly susceptible to lipoperoxidation. Br. J. Nutr. 2007, 98, 691-701. [CrossRef] [PubMed]

88. Leparmarai, P.T.; Sinz, S.; Kunz, C.; Liesegang, A.; Ortmann, S.; Kreuzer, M.; Marquardt, S. Transfer of total phenols from a grapeseed-supplemented diet to dairy sheep and goat milk, and effects on performance and milk quality. J. Anim. Sci. 2019, 97, 1840-1851. [CrossRef] [PubMed]

89. Muíño, I.; Apeleo, E.; de la Fuente, J.; Pérez-Santaescolástica, C.; Rivas-Cañedo, A.; Pérez, C.; Díaz, M.T.; Cañeque, V.; Lauzurica, S. Effect of dietary supplementation with red wine extract or vitamin E, in combination with linseed and fish oil, on lamb meat quality. Meat Sci. 2014, 98, 116-123. [CrossRef] [PubMed]

90. Biondi, L.; Randazzo, C.L.; Russo, N.; Pino, A.; Natalello, A.; Van Hoorde, K.; Caggia, C. Dietary supplementation of tanninextracts to lambs: Effects on meat fatty acids aomposition and stability and on microbial characteristics. Foods $2019,8,469$. [CrossRef]

91. Valenti, B.; Natalello, A.; Vasta, V.; Campidonico, L.; Roscini, V.; Mattioli, S.; Pauselli, M.; Priolo, A.; Lanza, M.; Luciano, G. Effect of different dietary tannin extracts on lamb growth performances and meat oxidative stability: Comparison between mimosa, chestnut and tara. Animal 2019, 13, 435-443. [CrossRef]

92. Gesteira, S.M.; Oliveira, R.L.; Trajano, J.; Ribeiro, C.; de Sousa Costa, E.I.; Ribeiro, R.D.X.; Pereira, E.S.; Bezerra, L.R. Fatty acid profile, physicochemical composition and sensorial attributes of salted and sun-dried meat from young Nellore bulls supplemented with condensed tannins. PLoS ONE 2019, 14, e0219581.

93. Staerfl, S.M.; Soliva, C.R.; Leiber, F.; Kreuzer, M. Fatty acid profile and oxidative stability of the perirenal fat of bulls fattened on grass silage and maize silage supplemented with tannins, garlic, maca and lupines. Meat Sci. 2011, 89, 98-104. [CrossRef]

94. Avila, A.S.; Zambom, M.A.; Faccenda, A.; Werle, C.H.; Almeida, A.R.E.; Schneider, C.R.; Grunevald, D.G.; Faciola, A.P. Black Wattle (Acacia mearnsii) condensed tannins as feed additives to lactating dairy cows. Animals 2020, 10, 662. [CrossRef]

95. Iglesias, J.; Pazos, M.; Torres, J.L.; Medina, I. Antioxidant mechanism of grape procyanidins in muscle tissues: Redox interactions with endogenous ascorbic acid and $\alpha$-tocopherol. Food Chem. 2012, 134, 1767-1774. [CrossRef]

96. Holst, B.; Williamson, G. Nutrients and phytochemicals: From bioavailability to bioefficacy beyond antioxidants. Curr. Opin. Biotechnol. 2008, 19, 73-82. [CrossRef] [PubMed]

97. Sallam, I.E.; Abdelwareth, A.; Attia, H.; Aziz, R.K.; Homsi, M.N.; von Bergen, M.; Farag, M.A. Effect of gut microbiota biotransformation on dietary tannins and human health implications. Microorganisms 2021, 9, 965. [CrossRef]

98. Ou, K.; Gu, L. Absorption and metabolism of proanthocyanidins. J. Funct. Foods 2014, 7, 43-53. [CrossRef]

99. Ottaviani, J.I.; Momma, T.Y.; Heiss, C.; Kwik-Uribe, C.; Schroeter, H.; Keen, C.L. The stereochemical configuration of flavanols influences the level and metabolism of flavanols in humans and their biological activity in vivo. Free. Radic. Biol. Med. 2011, 50, 237-244. [CrossRef] [PubMed]

100. Déprez, S.; Brezillon, C.; Rabot, S.; Philippe, C.; Mila, I.; Lapierre, C.; Scalbert, A. Polymeric proanthocyanidins are catabolized by human colonic microflora into low-molecular-weight phenolic acids. J. Nutr. 2000, 130, 2733-2738. [CrossRef]

101. Abia, R.; Fry, S.C. Degradation and metabolism of 14C-labelled proanthocyanidins from carob (Ceratonia siliqua) pods in the gastrointestinal tract of the rat. J. Sci. Food Agric. 2001, 81, 1156-1165. [CrossRef]

102. Mena, P.; Calani, L.; Bruni, R.; Del Rio, D. Bioactivation of high-molecular-weight polyphenols by the gut microbiome. In Diet-Microbe Interactions in the Gut; Tuohy, K., Del Rio, D., Eds.; Academic Press: San Diego, CA, USA, 2015 ; pp. 73-101. ISBN 978-0-12-407825-3.

103. Spencer, J.P.E.; Chaudry, F.; Pannala, A.S.; Srai, S.K.; Debnam, E.; Rice-Evans, C. Decomposition of cocoa procyanidins in the gastric milieu. Biochem. Biophys. Res. Commun. 2000, 272, 236-241. [CrossRef] [PubMed] 
104. Kahle, K.; Kempf, M.; Schreier, P.; Scheppach, W.; Schrenk, D.; Kautenburger, T.; Hecker, D.; Huemmer, W.; Ackermann, M.; Richling, E. Intestinal transit and systemic metabolism of apple polyphenols. Eur. J. Nutr. 2011, 50, 507-522. [CrossRef]

105. Gültekin-Özgüven, M.; Berktaş, I.; Özçelik, B. Change in stability of procyanidins, antioxidant capacity and in-vitro bioaccessibility during processing of cocoa powder from cocoa beans. LWT-Food Sci. Technol. 2016, 72, 559-565. [CrossRef]

106. Li, Q.; Chen, J.; Li, T.; Liu, C.; Wang, X.; Dai, T.; McClements, D.J.; Liu, J. Impact of in vitro simulated digestion on the potential health benefits of proanthocyanidins from Choerospondias axillaris peels. Food Res. Int. 2015, 78, 378-387. [CrossRef]

107. Rios, L.Y.; Bennett, R.N.; Lazarus, S.A.; Rémésy, C.; Scalbert, A.; Williamson, G. Cocoa procyanidins are stable during gastric transit in humans. Am. J. Clin. Nutr. 2002, 76, 1106-1110. [CrossRef]

108. Cires, M.J.; Wong, X.; Carrasco-Pozo, C.; Gotteland, M. The gastrointestinal tract as a key target organ for the health-promoting effects of dietary proanthocyanidins. Front. Nutr. 2017, 3, 57. [CrossRef]

109. Choy, Y.Y.; Quifer-Rada, P.; Holstege, D.M.; Frese, S.A.; Calvert, C.C.; Mills, D.A.; Lamuela-Raventos, R.M.; Waterhouse, A.L. Phenolic metabolites and substantial microbiome changes in pig feces by ingesting grape seed proanthocyanidins. Food Funct. 2014, 5, 2298-2308. [CrossRef] [PubMed]

110. Choy, Y.Y.; Jaggers, G.K.; Oteiza, P.I.; Waterhouse, A.L. Bioavailability of intact proanthocyanidins in the rat colon after ingestion of grape seed extract. J. Agric. Food Chem. 2013, 61, 121-127. [CrossRef]

111. Jimenez-Ramsey, L.M.; Rogler, J.C.; Housley, T.L.; Butler, L.G.; Elkin, R.G. Absorption and distribution of 14C-labeled condensed tannins and related sorghum phenolics in chickens. J. Agric. Food Chem. 1994, 42, 963-967. [CrossRef]

112. Quijada, J.; Drake, C.; Gaudin, E.; El-Korso, R.; Hoste, H.; Mueller-Harvey, I. Condensed tannin changes along the digestive tract in lambs fed with sainfoin pellets or hazelnut skins. J. Agric. Food Chem. 2018, 66, 2136-2142. [CrossRef]

113. Perez-Maldonado, R.A.; Norton, B.W. Digestion of ${ }^{14} \mathrm{C}$-labelled condensed tannins from Desmodium intortum in sheep and goats. Br. J. Nutr. 1996, 76, 501-513. [CrossRef] [PubMed]

114. Terrill, T.H.; Waghorn, G.C.; Woolley, D.J.; Mcnabb, W.C.; Barry, T.N. Assay and digestion of ${ }^{14}$ C-labelled condensed tannins in the gastrointestinal tract of sheep. Br. J. Nutr. 1994, 72, 467-477. [CrossRef] [PubMed]

115. Makkar, H.P.S.; Becker, K.; Abel, H.; Szegletti, C. Degradation of condensed tannins by rumen microbes exposed to quebracho tannins (QT) in rumen simulation technique (RUSITEC) and effects of QT on fermentative processes in the RUSITEC. J. Sci. Food Agric. 1995, 69, 495-500. [CrossRef]

116. Makkar, H.P.S.; Blümmel, M.; Becker, K. In vitro effects of and interactions between tannins and saponins and fate of tannins in the rumen. J. Sci. Food Agric. 1995, 69, 481-493. [CrossRef]

117. Makkar, H.P.S. Effects and fate of tannins in ruminant animals, adaptation to tannins, and strategies to overcome detrimental effects of feeding tannin-rich feeds. Small Rumin. Res. 2003, 49, 241-256. [CrossRef]

118. Jones, W.; Mangan, J.L. Complexes of the condensed tannins of sainfoin (Onobrychis viciifolia Scop.) with fraction 1 leaf protein and with submaxillary mucoprotein, and their reversal by polyethylene glycol and pH. J. Sci. Food Agric. 1977, 28, 126-136. [CrossRef]

119. Mueller-Harvey, I. Unravelling the conundrum of tannins in animal nutrition and health. J. Sci. Food Agric. 2006, 86, 2010-2037. [CrossRef]

120. Sánchez-Rangel, J.C.; Benavides, J.; Heredia, J.B.; Cisneros-Zevallos, L.; Jacobo-Velázquez, D.A. The Folin-Ciocalteu assay revisited: Improvement of its specificity for total phenolic content determination. Anal. Methods 2013, 5, 5990-5999. [CrossRef]

121. Halliwell, B.; Rafter, J.; Jenner, A. Health promotion by flavonoids, tocopherols, tocotrienols, and other phenols: Direct or indirect effects? Antioxidant or not? Am. J. Clin. Nutr. 2005, 81, 268S-276S. [CrossRef]

122. Kerem, Z.; Chetrit, D.; Shoseyov, O.; Regev-Shoshani, G. Protection of lipids from oxidation by epicatechin, trans-resveratrol, and gallic and caffeic acids in intestinal model systems. J. Agric. Food Chem. 2006, 54, 10288-10293. [CrossRef]

123. Yamamoto, M.; Miyamoto, S.; Moon, J.-H.; Murota, K.; Hara, Y.; Terao, J. Effect of dietary green tea catechin preparation on oxidative stress parameters in large intestinal mucosa of rats. Biosci. Biotechnol. Biochem. 2006, 70, 286-289. [CrossRef]

124. Gladine, C.; Morand, C.; Rock, E.; Gruffat, D.; Bauchart, D.; Durand, D. The antioxidative effect of plant extracts rich in polyphenols differs between liver and muscle tissues in rats fed n-3 PUFA rich diets. Anim. Feed. Sci. Technol. 2007, 139, 257-272. [CrossRef]

125. Frank, J. Beyond Vitamin E supplementation: An alternative strategy to improve vitamin E status. J. Plant Physiol. 2005, 162, 834-843. [CrossRef]

126. Frank, J.; Eliasson, C.; Leroy-Nivard, D.; Budek, A.; Lundh, T.; Vessby, B.; Aman, P.; Kamal-Eldin, A. Dietary secoisolariciresinol diglucoside and its oligomers with 3-hydroxy-3-methyl glutaric acid decrease vitamin E levels in rats. Br. J. Nutr. 2004, 92, 169-176. [CrossRef]

127. Facino, R.M.; Carini, M.; Aldini, G.; Calloni, M.T.; Bombardelli, E.; Morazzoni, P. Sparing effect of procyanidins from Vitis vinifera on vitamin E: In vitro studies. Planta Med. 1998, 64, 343-347. [CrossRef] [PubMed]

128. Sgorlon, S.; Stradaioli, G.; Zanin, D.; Stefanon, B. Biochemical and molecular responses to antioxidant supplementation in sheep. Small Rumin. Res. 2006, 64, 143-151. [CrossRef]

129. Puiggros, F.; Llópiz, N.; Ardévol, A.; Bladé, C.; Arola, L.; Salvadó, M.J. Grape seed procyanidins prevent oxidative injury by modulating the expression of antioxidant enzyme systems. J. Agric. Food Chem. 2005, 53, 6080-6086. [CrossRef] [PubMed]

130. da Costa, R.M.; Rodrigues, D.; Pereira, C.A.; Silva, J.F.; Alves, J.V.; Lobato, N.S.; Tostes, R.C. Nrf2 as a potential mediator of cardiovascular risk in metabolic diseases. Front. Pharmacol. 2019, 10, 382. [CrossRef] 
131. Suraweera, T.L.; Rupasinghe, H.P.V.; Dellaire, G.; Xu, Z. Regulation of Nrf2/ARE pathway by dietary flavonoids: A friend or foe for cancer management? Antioxidants 2020, 9, 973. [CrossRef]

132. Tebay, L.E.; Robertson, H.; Durant, S.T.; Vitale, S.R.; Penning, T.M.; Dinkova-Kostova, A.T.; Hayes, J.D. Mechanisms of activation of the transcription factor Nrf2 by redox stressors, nutrient cues, and energy status and the pathways through which it attenuates degenerative disease. Free. Radic. Biol. Med. 2015, 88, 108-146. [CrossRef]

133. Martínez-Huélamo, M.; Rodríguez-Morató, J.; Boronat, A.; de la Torre, R. Modulation of Nrf2 by olive oil and wine polyphenols and neuroprotection. Antioxidants (Basel) 2017, 6, 73. [CrossRef] [PubMed]

134. Upadhyay, S.; Dixit, M. Role of polyphenols and other phytochemicals on molecular signaling. Oxidative Med. Cell. Longev. 2015, 2015, 504253. [CrossRef] [PubMed] 